\title{
BMI: ANALYSIS OF THE POPULATION INDICATORS IN WORKING POPULATION OF THE REPUBLIC OF SERBIA IN RELATION TO GENDER AND AGE
}

\author{
Milivoj Dopsaj ${ }^{1}$, Stefan Marković ${ }^{2}$, Jovan Jovanović ${ }^{2}$, Vesna Vuković ${ }^{2}$, Miloš Maksimović ${ }^{3}$, Dragan Miljuš4, \\ Milena S. Tomanićs ${ }^{3}$, Zdravko Aničić ${ }^{2}$, Lazar D. Tomić ${ }^{1}$, Aleksandar Stanković ${ }^{2}$ \\ ${ }^{1}$ University of Belgrade, Faculty of Sport and Physical Education, Serbia \\ ${ }^{2}$ University of Belgrade, Faculty of Sport and Physical Education, Serbia, student DAS \\ ${ }^{3}$ University of Belgrade, Faculty of Medicine, Institute of Hygiene and Medical Ecology, Serbia \\ ${ }^{4}$ Institute of Public Health of Serbia "Dr Milan Jovanović Batut", Belgrade, Serbia
}

\begin{abstract}
Summary
The aim of this paper is to define the population indicators of the nutritional status among the working population of the Republic of Serbia based on the value of Body Mass Index (BMI). The sample consisted of a total of 7.125 working subjects, among which 4.525 males (63.51\%) and 2.600 females (36.49\%). The subjects were from the following regions: Northern Serbia-Vojvodina, Capital city - Belgrade, Central Serbia, Western Serbia, Southern Serbia and Eastern Serbia. The average BMI values based on test groups of men and women were $26.53 \pm 4.07$ and $24.07 \pm 5.09 \mathrm{~kg} \cdot \mathrm{m}^{-2}$, respectively. On the basis of the obtained results, it was determined that statistically significant BMI differences exist among subjects in general, i.e. in relation to gender $(\mathrm{F}=58.412, \mathrm{p}<0.000)$, the age category $(\mathrm{F}=268.885, \mathrm{p}<0.001)$ as well as the interaction of the given factors $(\mathrm{F}=18.203 . \mathrm{p}<0.000)$. In relation to the prevalence, for the female subsample, it was determined that $65.3 \%$ of the subjects are in the optimal weight category, $18.7 \%$ are overweight, $12.5 \%$ are obese and $3.6 \%$ of are in the underweight category. When it comes to the male test group, the underweight prevalence of $0.2 \%$ was established. Percentage of subjects in the categories of optimal weight, overweight and obesity was 37.9, 48.0 and 13.9\%, respectively. The highest prevalence of overweight and obesity was found at the age of 60-65 years. In the male test group, it was determined that $45.2 \%$ of the subjects were pre-obese and $26.0 \%$ were obese. In relation to the female subsample, the prevalence of overweight was found to be at the level of $36.8 \%$, while the prevalence of obesity was as high as $41.4 \%$. On the basis of the defined models of nutrition status in relation to age, it was found that the established BMI growth constant is $0.0904 \mathrm{~kg} \cdot \mathrm{m}^{-2}$, that is $90.4 \mathrm{~g} \cdot \mathrm{m}^{-2}$ per year of life for the male subsample, while for the female subsample growth constant is at the level of $0.1767 \mathrm{~kg} \cdot \mathrm{m}^{-2}$, that is $176.7 \mathrm{~g} \cdot \mathrm{m}^{-2}$ per year of life.
\end{abstract}

Keywords: LEVEL OF NUTRITION / PREVALENCE OF OBESITY / GENDER / AGE / TREND OF CHANGES

\section{INTRODUCTION}

Not only do overweight and obesity affect everyday life, but it also significantly affect the working ability and productivity of the population (Bruffaerts et al., 2008). Persons whose weight exceeds the average values that are characteristic for their age and gender are $12 \%$ more absent from work than the ones with optimal weight. When it comes to obese persons, the situation is more alarming. The absence from work is as high as $30 \%$ (Bungum et al., 2003) causing a decline in productivity (Katzmarzyk \& Janssen, 2004), while costs of treatment and healthcare are sig- nificantly higher than in persons with a normal body mass index (Bungum et al., 2003 Jackson et al., 2005).

Body Mass Index (abbr. BMI) is a widely accepted morphologically-nutritive indicator of the nutritional status and the World Health Organization (WHO) considers it the standard for defining the level of obesity (WHO, 2000). Although BMI, as an universal indicator of nutrition status, is not sufficiently discriminative in relation to racial disparities or when considering certain specific categories of subjects, such as children, athletes, persons employed in military and 
security services etc. (Prentice \& Jebb, 2001), BMI remains in use as a simple, non-invasive and reliable parameter commonly used for assessment of nutritional status and monitoring the tendencies of nutrition and obesity in the widest population (ĐorđevićNikić et al., 2013).

The trend of an increment in the number of overweight and obese people is more and more visible (Finucane et al., 2011). At a global level, obesity has increased by $7.6 \%$ in men and $8.5 \%$ in women over the last 40 years (NCD Risk Factor Collaboration, 2016). It is estimated that in the year 2008 there were almost one billion five hundred million people with a BMI value higher than $25 \mathrm{~kg} \cdot \mathrm{m}^{-2}$ in the world (Finucane et al., 2011). Gaining weight above the age and gender average level is no longer exclusively the problem of highly developed countries. Developing countries are equally affected by negative changes (Weisell, 2002; Kelly et al., 2008), and there are noticeable differences between urban and rural areas (Jackson et al., 2005).

A comprehensive research which included more than nine million participants determined that men $\left(33.9 \mathrm{~kg} \cdot \mathrm{m}^{-2}\right)$ and women $\left(35.0 \mathrm{~kg} \cdot \mathrm{m}^{-2}\right)$ from the Oceania region have the highest average BMI values (WHO, 2000; Finucane et al., 2011). In Sub-Saharan Africa, eastern, northern and north-eastern Asia, average BMI values lower than $21.5 \mathrm{~kg} \cdot \mathrm{m}^{-2}$ are characteristic for both man and women (Finucane et al., 2011). In relation to the developed countries, the United States are leading when it comes to high BMI values in comparison to the rest of the world (Finucane et al., 2011). Nevertheless, authors emphasize the important differences in groups of different ethnic origin and socioeconomic status (Flegal et al., 2004; Krishna et al., 2015). The highest mean BMI value of $28.4 \mathrm{~kg} \cdot \mathrm{m}^{-2}$ was determined among men in North America, while in Australia BMI is at the level of $27.6 \mathrm{~kg} \cdot \mathrm{m}^{-2}$ (Finucane et al., 2011). When it comes to women, the global increase in body weight of 0.5 $\mathrm{kg} \cdot \mathrm{m}^{-2}$ per decade has been noticed. The increase in BMI value is most noticeable in women who live in Oceania, followed by women in Latin American (Finucane et al., 2011).

Contrary to some findings presented by Jackson et al. (2005), the prevalence of obesity in ten European countries showed that there were no significant differences in the average BMI values in rural and urban areas, except in Greece (Peytremann-Bridevaux et al., 2007). The reasons for the variability of BMI value could be found in socio-economic status and predominant lifestyle (Lakerveld et al., 2015). The highest number of overweight Europeans with a body mass index in the range of 25.0 to $29.9 \mathrm{~kg} \cdot \mathrm{m}^{-2}$ lives in Greece (48.1\%) and Spain (45.4\%), and the smallest in Switzerland (37.9\%). Countries with the highest number of obese people whose BMI is larger than $30.0 \mathrm{~kg} \cdot \mathrm{m}^{-2}$ are Spain (24.0\%), Greece (20.8\%) and Austria (19.9\%) (Peytremann-Bridevaux et al., 2007).

The current data indicate that there are high BMI values among the adult population in the Republic of Serbia . Vojvodina is the area with the highest prevalence of overweight (33.5\%) and obesity (23.0\%) (Pavlica et al., 2010), and these results are confirmed by a research conducted among adult population in Backa and Banat, where the percentage of overweight is at the level of $45.1 \%$ in men and $32.0 \%$ in women, while the percentage of obesity is $21.2 \%$ in men and $17.7 \%$ in women (Pavlica et al., 2012). The data obtained from the sample of working women from the territory of the city of Belgrade, where over $55 \%$ of participants had optimal weight, $30 \%$ were pre-obese and $10 \%$ were obese, confirms that differences in BMI in relation to region exist. It should be emphasized that this study was conducted on a sample of a limited size that included only 109 participants, out of which almost $69 \%$ were physically active (Djordjevic-Nikic et al., 2013).

For the purposes of continuous monitoring of the nutritional status of the population and for the more precise definition of analysis of the status of current population indicators, it is necessary to provide valid and referential data. This particularly refers to the period of the beginning of the third millennium, when a significant negative change in the prevalence of undesirable BMI categories, that is, pre-obese and obese persons is established. In relation to the previous, the primary goal of this study is to determine the population indicators of the nutritional status in relation to age and gender among the working population of the Republic of Serbia (RS).

\section{METHODS}

This research is non-experimental and transversal. In regard to the type of measurement used in the research, the method applied was laboratory testing. 


\section{The research sample}

The sample in this research consisted of a total of 7.125 working subjects, mean age $32.3 \pm 10.4$, among which $4525(63.51 \%)$ men, mean age $32.9 \pm 11.3$ years, and $2600(36.49 \%)$ women, mean age $32.0 \pm 9.8$ years. Subjects were divided into subsamples in relation to gender and age. Therefore, there were five test groups both for men and women. Within the overall sample, the majority of participants were from the age group 18 -30 years $(45.68 \%)$, while the smallest number of participants were from the age group 60-65 years (1.94\%). The basic descriptive indicators for the male subjects were $\mathrm{TV}=181.61 \pm 6.76 \mathrm{~cm}$ and $\mathrm{TM}=$ $87.68 \pm 14.73 \mathrm{~kg}$, while for female subjects the average body height and body weight were $168.07 \pm 6.70 \mathrm{~cm}$ and $67.83 \pm 13.88 \mathrm{~kg}$, respectively. All subjects were residents of the Republic of Serbia - from the territory of Vojvodina, the city of Belgrade, as well as the regions of Central, Western, Southern and Eastern Serbia. At the level of the overall sample, the subjects were residents of 62 cities with the following percentage representation in the regions: Belgrade and its suburbs $25.17 \%$, Vojvodina $29.77 \%$, Central Serbia 17.88\%, Southern and Eastern Serbia 12.58\% and Western Serbia 14.60\%, whereby methodological conditions for acceptance of the results at the level of population studies were provided.

All subjects were familiar with the aim of the research and they voluntarily accepted to participate in it. The research was conducted in accordance with the postulates of the Declaration of Helsinki and with the approval of the Ethics Committee of the University of Belgrade, Faculty of Sport and Physical Education.

\section{Measurement methods}

All measurements were carried out in the period of the year 2011 to 2018. in the of Methodical Research Laboratory of the Faculty of Sport and Physical Education, University of Belgrade, as well as at the Institute of Hygiene and Medical Ecology of the Medical Faculty, University of Belgrade. The measurements were carried out by the method of multichannel $(1,5$, $50,250,500,1000 \mathrm{kHz}$ ) bioimpedance (MBI), using a standardized testing procedure and a body structure analyzer of the latest generation - InBody 720 (Biospace Co., Ltd, Seoul, Korea) was used.

The measurement of body height $(\mathrm{BH})$ was conducted in the morning (08:00-10: $00 \mathrm{AM}$ ) using an anthropometer (GPM, Swiss-made), while the measurement of body weight (BW) was conducted using the above-mentioned instrument InBody 720 in accordance with the standardized procedure described in previous literature (Gaba et al., 2015). Measurement of $\mathrm{BH}$ and $\mathrm{BW}$ was performed by experienced examiners.

The subsamples were defined according to the recommendations of the $\mathrm{WHO}$ in relation to the following 5 age categories: $18-29.9 ; 30-39.9 ; 40-49.9 ; 50$ 59.9; 60-65.0 years, with the correction for the first age group.

\section{Variables}

The BMI (Body Mass Index) is a commonly accepted indicator of the nutritional status, i.e. the measure of the nutritional status of the body. BMI represents the ratio of body mass (BM) and squared body height $(\mathrm{BH})$, expressed in $\mathrm{kg} \cdot \mathrm{m}^{-2}$. The standard WHO classification of nutrition level is: underweight $\mathrm{BMI}<18.5 \mathrm{~kg} \cdot \mathrm{m}^{-2}$; optimal weight $\mathrm{BMI}=18.5-24.99$ $\mathrm{kg} \cdot \mathrm{m}^{-2}$; overweight $\mathrm{BMI}=25.00-29.99 \mathrm{~kg} \cdot \mathrm{m}^{-2}$; obesity (type 1) $\mathrm{BMI}=30.00-34.99 \mathrm{~kg} \cdot \mathrm{m}^{-2}$; obesity (type 2 ) $\mathrm{BMI}=35.00-39.99 \mathrm{~kg} \cdot \mathrm{m}^{-2}$; obesity (type 3 ) $\mathrm{BMI} \geq 40.00$ $\mathrm{kg} \cdot \mathrm{m}^{-2}$; (WHO, 2000).

\section{The statistical analysis}

All raw data has been analyzed using methods of descriptive and analytical statistics. All relevant measures of central tendency, dispersion an range of data (MEAN, SD, MIN, MAX, KURT, SKEW, $\mathrm{SE}_{\mathrm{M}}$, $\mathrm{CV} \%$ ) were calculated for the examined variable in relation to overall sample and individual subsamples as well as in relation to age and gender. The normality of the distribution of the results was determined by application of the nonparametric KolmogorovSmirnov goodness of fit test (K-S Z). General differences in relation to age and gender of the participants as well as in relation to the interaction of these factors were tested using Factorial analysis of variance (Factorial ANOVA). Partial differences between the defined subsamples were determined by application of post hoc tests using Bonferroni correction. All data analyses were conducted using Excel 2013 and IBM SPSS v.23 statistical software. The level of statistical significance was defined for the probability of $95 \%$, i.e. $\mathrm{p} \leq 0.05$. 


\section{RESULTS}

Table 1. Basic descriptive statistics of the examined variable in relation to the defined subsamples

\begin{tabular}{|c|c|c|c|c|c|c|c|c|c|c|c|c|}
\hline \multicolumn{13}{|c|}{ Descriptive statistics for the BMI variable } \\
\hline Group & $\mathbf{N}$ & $\begin{array}{c}\text { Mean } \\
\left(\mathrm{kg} \cdot \mathrm{m}^{-2}\right)\end{array}$ & $\begin{array}{c}\text { Std. } \\
\text { Error } \\
\text { Mean } \\
\left(\mathbf{k g} \cdot \mathbf{m}^{-2}\right)\end{array}$ & $\begin{array}{l}\text { Std. } \\
\text { Error } \\
\text { Mean } \\
\%\end{array}$ & $\begin{array}{c}\mathrm{SD} \\
\left(\mathrm{kg} \cdot \mathrm{m}^{-2}\right)\end{array}$ & cV\% & $\underset{\left(\mathrm{kg} \cdot \mathrm{m}^{-2}\right)}{\operatorname{Min}}$ & $\underset{\left(\mathrm{kg} \cdot \mathrm{m}^{-2}\right)}{\operatorname{Max}}$ & Skew. & Kurt. & K-S Z & $\begin{array}{c}\mathrm{K}-\mathrm{S} \\
\text { (p value) }\end{array}$ \\
\hline Total & 7125 & 25.63 & 0.05 & 0.21 & 4.62 & 18.03 & 14.43 & 63.47 & 1.42 & 4.52 & 0.072 & 0.000 \\
\hline Women & 2600 & 24.07 & 0.10 & 0.41 & 5.09 & 21.13 & 14.43 & 63.47 & 1.81 & 5.54 & 0.127 & 0.000 \\
\hline Women, $18-30$ years & 1178 & 22.18 & 0.11 & 0.50 & 3.80 & 17.13 & 14.43 & 48.63 & 2.22 & 7.04 & 0.160 & 0.000 \\
\hline Women, $30-40$ years & 735 & 24.64 & 0.20 & 0.81 & 5.38 & 21.84 & 16.57 & 49.64 & 1.56 & 2.87 & 0.141 & 0.000 \\
\hline Women, 40-50 years & 430 & 25.69 & 0.23 & 0.88 & 4.67 & 18.17 & 16.57 & 56.28 & 1.76 & 6.93 & 0.114 & 0.000 \\
\hline Women, 50-60 years & 181 & 27.48 & 0.37 & 1.35 & 4.99 & 18.17 & 17.15 & 41.69 & 0.49 & -0.15 & 0.060 & 0.200 \\
\hline Women, 60-65 years & 76 & 30.57 & 0.86 & 2.82 & 7.53 & 24.62 & 21.52 & 63.47 & 2.33 & 8.05 & 0.141 & 0.001 \\
\hline Men & 4525 & 26.53 & 0.06 & 0.23 & 4.07 & 15.34 & 15.89 & 52.90 & 1.64 & 5.30 & 0.091 & 0.000 \\
\hline Men, $18-30$ years & 2077 & 24.91 & 0.07 & 0.29 & 3.29 & 13.22 & 15.89 & 51.39 & 2.19 & 10.37 & 0.100 & 0.000 \\
\hline Men, 30-40 years & 1498 & 27.74 & 0.11 & 0.40 & 4.26 & 15.34 & 18.59 & 52.90 & 1.76 & 5.79 & 0.110 & 0.000 \\
\hline Men, $40-50$ years & 704 & 28.14 & 0.15 & 0.55 & 4.07 & 14.48 & 18.65 & 49.16 & 1.25 & 3.23 & 0.091 & 0.000 \\
\hline Men, 50-60 years & 184 & 28.01 & 0.24 & 0.86 & 3.25 & 11.61 & 19.57 & 40.26 & 1.10 & 2.40 & 0.129 & 0.000 \\
\hline Men, 60-65 years & 62 & 28.62 & 0.64 & 2.24 & 5.04 & 17.61 & 20.99 & 42.77 & 1.04 & 0.70 & 0.140 & 0.004 \\
\hline
\end{tabular}

On the basis of the presented results (Table 1), it can be argued that BMI data is homogeneous, that the coefficient of variation ranges from $11.61 \%$, for BMI values of 50 to 60 -year-old men, up to $24.62 \%$, for 60 to 65 -year-old women. Also, it should be pointed out that asymmetric positively oriented shape of the distribution of the results was determined in all subsam- ples (Skewness ranges from 0.49 for the sample of 50 to 60 -year-old females up to 2.33 for the sample of 60 to 65 -year-old females). Considering the shape of the distribution of the results in relation to peakedness, a high level of variation was determined. The values of Kurtosis range from -0.15 (50 to 60-year-old women) up to 10.37 ( 28 to 30 -year-old men). 
Dopsaj M., et al., BMI: Analysis of the Population Indicators..., PHYSICAL CULTURE 2018; 72 (2): 148-160

Table 2. Results of the Factorial ANOVA for the tested variable in relation to gender and age of participants

Result of the Factorial analysis of variance in relation to age and gender of participants

\begin{tabular}{lccccccc}
\hline Dependent variable: BMI & \multicolumn{1}{c}{ M } & & & & \\
\hline Source & $\begin{array}{c}\text { Type III Sum } \\
\text { of Squares }\end{array}$ & df & $\begin{array}{c}\text { Mean } \\
\text { Square }\end{array}$ & F & Sig. & $\begin{array}{c}\text { Partial Eta } \\
\text { Squared }\end{array}$ & $\begin{array}{c}\text { Observed } \\
\text { Power }\end{array}$ \\
\hline Gender & 994.418 & 1.000 & 994.418 & 58.412 & 0.000 & 0.008 & 1.000 \\
Age & 18310.233 & 4.000 & 4577.558 & 268.885 & 0.000 & 0.131 & 1.000 \\
Gender•Age & 1239.555 & 4.000 & 309.889 & 18.203 & 0.000 & 0.010 & 1.000 \\
\hline
\end{tabular}

The results of Factorial analysis of variance (Factorial ANOVA) have shown that a statistically significant difference in BMI values exists in relation to gender $(\mathrm{F}=58.412, \mathrm{p}<0.000)$ and age category $(\mathrm{F}=268.885, \mathrm{p}<0.001)$. Also, a statistically significant interaction of age and gender $(\mathrm{F}=18.203$. $\mathrm{p}<0.000)$ has been determined.

Table 3. Partial differences between age groups in relation to gender

\begin{tabular}{|c|c|c|c|c|c|}
\hline \multicolumn{6}{|c|}{ Pairwise comparisons of different age groups in relation to gender } \\
\hline \multicolumn{6}{|c|}{ Dependent variable:BMI } \\
\hline Age & Gro & & $\begin{array}{c}\text { Main } \\
\text { Difference }\end{array}$ & Std. Error & Sig. \\
\hline $18-30$ & Women & Men & -2.729 & 0.150 & 0.000 \\
\hline $30-40$ & Women & Men & -3.103 & 0.186 & 0.000 \\
\hline $40-50$ & Women & Men & -2.447 & 0.253 & 0.000 \\
\hline $50-60$ & Women & Men & -0.533 & 0.432 & 0.217 \\
\hline $60-65$ & Women & Men & 1.951 & 0.706 & 0.006 \\
\hline
\end{tabular}

Results of a series of post hoc tests Bonferroni (Table 3) have shown a statistically significant difference $(\mathrm{p}<0.001)$ in BMI values in relation to gender for four age categories (18-30,
$30-40,40-50 \& 60-65$ years) while in the case of 50 to 60-year-old participants determined differences were not statistically significant $(\mathrm{p}=0.217)$. 


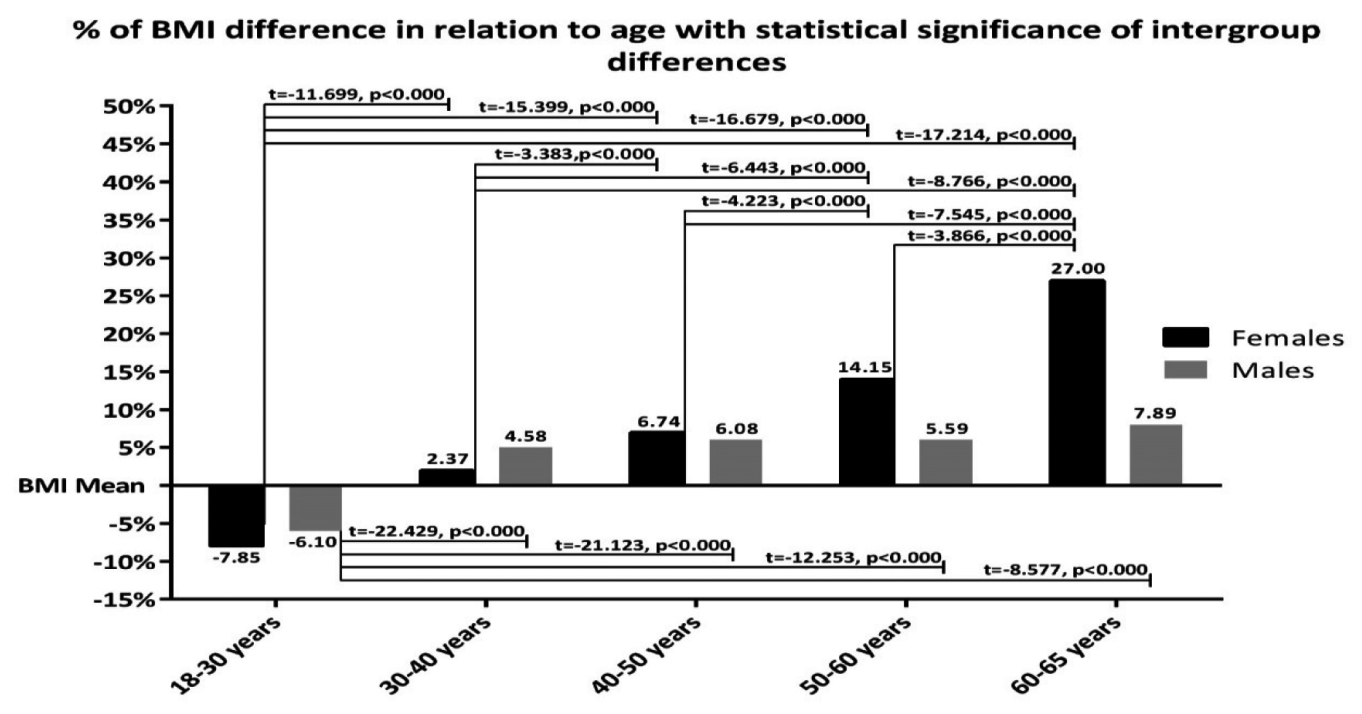

Graph1. Percentage differences in standardized BMI values in relation to the average value of the overall sample in function of gender with the statistical significance of differences between individual age groups

Graph 1 shows the percentage difference in mean BMI value for distinct age subgroups in relation to gender, as well as the statistical significance of differences between age groups within subsamples of men and women. Among female participants, statis- tically significant differences $(\mathrm{p}<0.000)$ between all age groups were determined. When it comes to male participants, only the age group of 18 -30 years significantly differs from others $(\mathrm{p}<0.000)$.

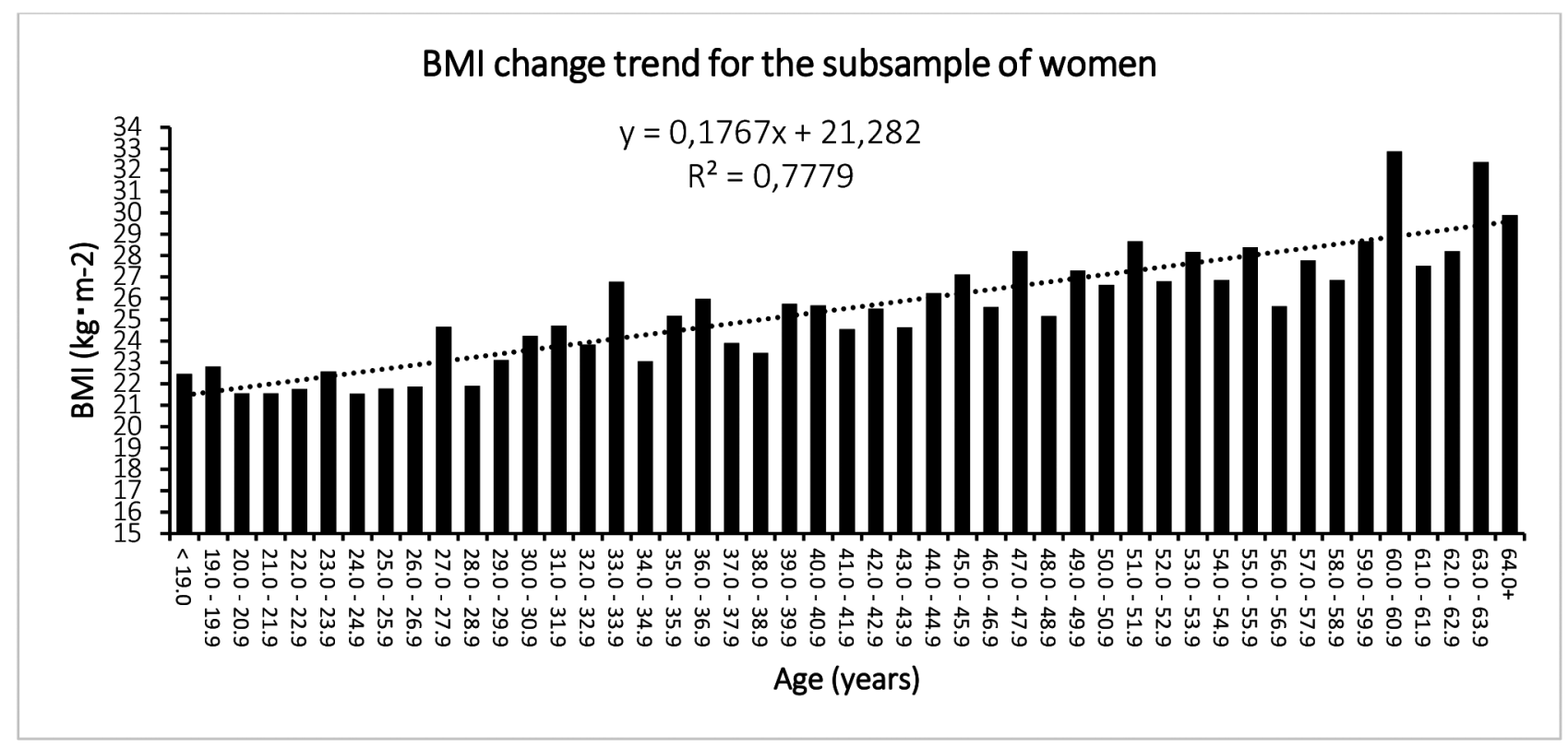

Graph 2. A regression model with the BMI change trend for the subsample of working women 
Models of dependency of BMI change in relation to age of participants are shown in Graphs 2 and 3. Based on the results it can be argued that, on a general level, working men are characterized by higher $\mathrm{BMI}$ values compared to women. The increase in BMI value during working life is linear in women while in men increase in BMI is nonlinear, i.e. it is more intensive until the age of 40 whereupon less intensive change was established. This was determined by application of $3^{\text {rd }}$ order polynomial function.

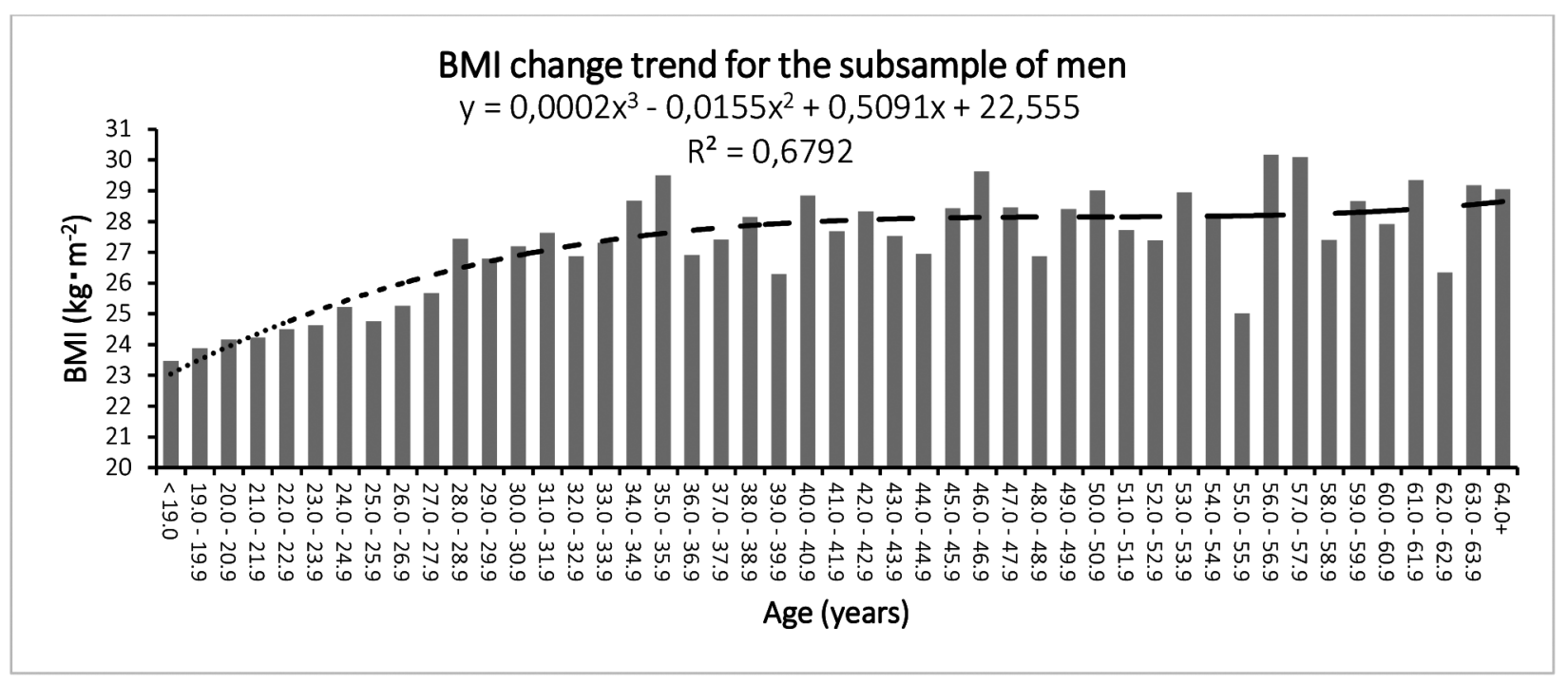

Graph 3. A regression model with the BMI change trend for the subsample of working men

Table 4 shows the prevalence of different categories of nutritional status based on the BMI value in relation to the gender and age of participants 
Dopsaj M., et al., BMI: Analysis of the Population Indicators..., PHYSICAL CULTURE 2018; 72 (2): 148-160

Table 4. The prevalence of Body Mass Index (BMI) in relation to characteristic categories of the given variable in function of gender and age of participants

\begin{tabular}{|c|c|c|c|c|c|c|c|}
\hline \multicolumn{8}{|c|}{ BMI - Prevalence } \\
\hline \multirow{2}{*}{ Group } & \multirow{2}{*}{$\begin{array}{c}\text { Underweight } \\
<18.49\end{array}$} & \multirow{2}{*}{$\begin{array}{c}\text { Normal weight } \\
18.5-24.99\end{array}$} & \multirow{2}{*}{$\begin{array}{c}\text { Overweight } \\
25-29.99\end{array}$} & \multirow{2}{*}{$\begin{array}{c}\text { Obese type I } \\
30-34.99\end{array}$} & \multirow{2}{*}{$\begin{array}{c}\begin{array}{c}\text { Obese } \\
\text { typeII }\end{array} \\
35-39.99\end{array}$} & \multicolumn{2}{|c|}{ Obese type III } \\
\hline & & & & & & $40-49.99$ & $50+$ \\
\hline Total & 1.4 & 47.9 & 37.3 & 9.4 & 2.9 & 1.0 & 0.1 \\
\hline Women & 3.6 & 65.3 & 18.7 & 8.2 & 3.1 & 1.0 & 0.2 \\
\hline Women, 18 -30 years & 5.9 & 79.6 & 9.0 & 3.7 & 1.5 & 0.3 & 0.0 \\
\hline Women, $30-40$ years & 2.2 & 64.1 & 18.8 & 8.8 & 4.5 & 1.6 & 0.0 \\
\hline Women, $40-50$ years & 1.6 & 48.4 & 35.1 & 11.9 & 2.1 & 0.5 & 0.5 \\
\hline Women, $50-60$ years & 0.6 & 35.9 & 34.3 & 19.3 & 7.7 & 2.2 & 0.0 \\
\hline Women, $60-65$ years & 0.0 & 19.7 & 36.8 & 25.0 & 9.2 & 6.6 & 2.6 \\
\hline Men & 0.2 & 37.9 & 48.0 & 10.0 & 2.8 & 1.0 & 0.1 \\
\hline Men, 18 - 30 years & 0.3 & 58.0 & 36.2 & 3.7 & 1.3 & 0.4 & 0.1 \\
\hline Men, $30-40$ years & 0.0 & 22.6 & 57.5 & 14.6 & 3.7 & 1.5 & 0.3 \\
\hline Men, $40-50$ years & 0.0 & 19.2 & 56.7 & 18.2 & 4.4 & 1.6 & 0.0 \\
\hline Men, $50-60$ years & 0.0 & 11.4 & 71.7 & 12.0 & 4.3 & 0.5 & 0.0 \\
\hline Men, $60-65$ years & 0.0 & 25.8 & 45.2 & 16.1 & 8.1 & 4.8 & 0.0 \\
\hline
\end{tabular}

\section{DISCUSSION}

The aim of this paper was to define population indicators of nutritional status based on Body Mass Index (BMI) values among the working population in the Republic of Serbia. The obtained results indicate that the values of the examined variable (BMI) are in the acceptable range of results, given the fact that the coefficient of variation $(\mathrm{cV} \%)$, as a relative measure of variability of the results, has a value lower than $30 \%$ for the overall sample and all subsamples. In other words, the obtained results meet the relevant criteria of homogeneity (Perić, 2003), and thus can be considered representative in terms of further scientific validation.

On a general level, the results of the applied Factorial analysis of variance indicate that a statistically significant difference in BMI values exist between men and women $(\mathrm{F}=58.412, \mathrm{p}<0.000)$, in relation to age categories $(\mathrm{F}=268.885, \mathrm{p}<0.001)$ and in relation to interaction of these factors $(\mathrm{F}=18.203 . \mathrm{p}<0.000)$ (Table 2).

Based on the obtained results (Table 3), it can be argued that statistically significant differences $(\mathrm{p}<0.01)$ in BMI values exist between men and women aged $18-30,30-40,40-50$, and 60-65 years, while at the age of 50-60 years, BMI differences in relation to gender are not statistically significant ( $\mathrm{p}=0.217$ ) (Table 3 ). In relation to the differences between age groups within male subsample, based on the obtained results (Graph 1 ) it can be argued that men aged 18-30 years have statistically significantly lower BMI values compared to all other groups ( $p<0.01$ ), while the differences between age groups $30-40,40-50,50-60$ and 60-65 years are not statistically significant. Based on the obtained results and in relation to the differences between age groups within the male subsample it can be argued that males aged 18-30 years have statistically significantly lower BMI values compared to all other groups $(p<0.01)$. The differences between age groups $30-40$, $40-50,50-60$ and $60-65$ were not statistically signifi- 
cant (Table 3). In relation to the differences between age groups within the subsample of male participants based on the obtained results (Graph 1), it can be argued that men between the age of 18-30 years have statistically significantly lower BMI values compared to all other groups $(\mathrm{p}<0.01)$, while the differences between age groups 30-40, 40-50, 50-60 and 60-65 are not statistically significant. When it comes to female participants, there were statistically significant differences regarding BMI values among all tested groups in relation to age groups $(\mathrm{p}<0.01)$.

In regard to the presented results, it should be emphasized that the percentage differences in BMI in terms of the average values of the sample in relation to gender indicate that in both men and women, the body mass index is statistically significantly lower in the age of 18 -30 years ( 6.1 and $7.85 \%$ respectively). In all other subsamples in relation to age, higher than average BMI values were determined with the tendency of increasing differences with each following age category . This is particularly visible at the level of female subsample where the average BMI of the group aged between $60-65$ years is $27 \%$ higher than the average of the overall female sample. This was also found in men where BMI in the eldest group is, on average, higher by $7.89 \%$ in comparison to the average of the overall male sample (Graph 1).

By applying a dependency model, the specification equation was defined through which the current trend in the increase of the body mass index according to age (per year of life) was established. Within the overall sample of male participants, the given BMI model is defined by the equation $\mathrm{y}=0.0002 \cdot \mathrm{x} 3$ $0.0155 \cdot \mathrm{x} 2+0.5091 \cdot \mathrm{x}+22.555$ with the coefficient of determination at the level of $\mathrm{R}^{2}=0.68$ (Graph 2), that is the model is defined by a linear function of the following form: $y=0.0904 x+25.099$ with coefficient of determination $\mathrm{R}^{2}=0.50$. In other words, the established rate of increase in BMI is $0.0904 \mathrm{~kg} \cdot \mathrm{m}^{2}$ or $90.4 \mathrm{~g} \cdot \mathrm{m}^{2}$ per year of life.

For the female subsample, the trend of increase in BMI value is defined by the equation $y=0.1767 \cdot x+$ 21.282 , with a slightly higher percentage of explained variance $\left(\mathrm{R}^{2}=0.78\right)$ (Chart 3$)$, that is, the increase constant of the level of nutrition was determined to be $0.1767 \mathrm{~kg} \cdot \mathrm{m}^{-2}$, that is $176.7 \mathrm{~g} \cdot \mathrm{m}^{-2}$ per year of life.

Even though in both cases, that is for both samples in relation to gender, a positive trend in body weight gain per unit area of the body has been established, it can be argued that BMI values in relation to age among women increase linearly with a constant $\mathrm{k}=0.1767$ while men experience an intensive increase in BMI in the period up to 40 years to a value of approximately $28 \mathrm{~kg} \cdot \mathrm{m}^{2}$, after which the annual increase in BMI values stagnates. Therefore men maintain relatively unchanged values of the above-mentioned index until the end of the working life.

In regard to the determined values of the average BMI at the level of the overall sample, it can be argued that the working population of the Republic of Serbia is characterized by the value of the given index at the level of $25.63 \pm 0.21 \mathrm{~kg} \cdot \mathrm{m}^{-2}$, which corresponds to the WHO data according to which BMI within the Republic of Serbia is around an average value of $26.1 \mathrm{~kg} \cdot \mathrm{m}^{2}$. When the obtained data is compared to the WHO data for the territory of Europe, it can be claimed that in relation to the given indicator of the nutritional status the Republic of Serbia is in the category of countries with slightly lower average BMI values, such as the Netherlands, Portugal, and Italy where average BMI is at the same level. Considering the fact that the values of the body mass index in the neighboring countries are in the range of $25.8 \mathrm{~kg} \cdot \mathrm{m}^{-2}$ for the territory of Bosnia and Herzegovina to 27.4 $\mathrm{kg} \cdot \mathrm{m}^{-2}$ for the Republic of Croatia, it can be argued that the values of the given indicator determined by this research are somewhat lower than the regional average. This can be considered desirable regarding the values themselves (WHO, 2014). However, knowing that there is a decades-long global trend of increase in BMI (NCD Risk Factor Collaboration, 2016), regardless of the previously mentioned, the nutritional status of the working population of the Republic of Serbia, can be considered alarming.

When considered in relation to the sample of working women in the Republic of Serbia, the established BMI values at the average level of $24.07 \pm 5.09$ $\mathrm{kg} \cdot \mathrm{m}^{-2}$ correspond to the category of people with optimal weight. The results obtained with this research are similar to those obtained on a female sample from the urban center of Belgrade where average BMI value of $24.2 \pm 4.66 \mathrm{~kg} \cdot \mathrm{m}^{-2}$ was determined (DjordjevicNikic et al., 2013), as well as with the results of the research that included women around the world where average BMI values of $24.1 \mathrm{~kg} \cdot \mathrm{m}^{-2}$ were determined (Finucane et al., 2011). When observed in relation to age, differences in BMI average values are visible, whereby the obtained data indicate that there is a negative tendency of permanent weight gain. In this sense, until the age of thirty years, working women 
belong to optimal weight group with average BMI values of $22.18 \mathrm{~kg} \cdot \mathrm{m}^{-2}$. From the age of thirty, they are at the upper level of normal nutritional status with BMI values of $24.64 \mathrm{~kg} \cdot \mathrm{m}^{2}$, and then in the fifth and sixth decade of life, they enter the overweight category with BMI higher than the recommended WHO value. Such findings correlate with the research of other authors that confirm the statistical significance of the relationship between age and obesity (Pavlica and associates, 2012; Kelly et al., 2008). After the age of 60 years, women enter the category of obesity due to the weight gain trend of $0.1767 \mathrm{~kg} \cdot \mathrm{m}^{-2}$ per year. The average BMI value of $30.57 \mathrm{~kg} \cdot \mathrm{m}^{-2}$ established in the sample of 60-65 years old women is higher than the value found in a sample of men of the same age, where BMI value is at the level of $28.62 \mathrm{~kg} \cdot \mathrm{m}^{-2}$. This data confirms the findings that indicate a constantly increased prevalence of obesity in women compared to men established worldwide (Kelly et al., 2008). Considering that almost $20 \%$ of the population does not think about health when choosing a diet, and the fact that only $8.8 \%$ of the population is physically active (men are more active than women) (Institute of Public Health of Serbia [IPHS], 2016), a high percentage of overweight and obese women (31.2\%) at the general level, as well as at the level of all tested groups has been as expected.

In relation to the results obtained on the male subsample, it was determined that the average value of the body mass index was $26.53 \pm 4.07 \mathrm{~kg} \cdot \mathrm{m}^{2}$. In accordance with the preceding, it can be argued that the working men in the Republic of Serbia, disregarding stratification in relation to age, can be classified as overweight, which is in accordance with the results obtained in some parts of Vojvodina (Pavlica et al., 2010). Nevertheless, the worrying fact is that the values of the given indicator of nutrition status are only slightly lower in comparison to Australia and the United States, where the average BMI values of 27.6 and $28.4 \mathrm{~kg} \cdot \mathrm{m}^{-2}$ have been determined, respectively (Finucane et al., 2011) given the fact that these countries are in the world's leading countries when it comes to the problem of overweight, that is obesity of the population. Taking into account the sample stratification in relation to age, it can be argued that the lowest BMI values of $24.91 \pm 3.29 \mathrm{~kg} \cdot \mathrm{m}^{-2}$ have been determined at the age of 18-30 years, which can be considered a limit value in relation to overweight. At the age of 30-40 years, BMI values in males reach an average of $27.74 \pm 4.26 \mathrm{~kg} \cdot \mathrm{m}^{-2}$, while after the age of forty years there is an evident stagnation of BMI growth, which stays around $28 \mathrm{~kg} \cdot \mathrm{m}^{-2}$ until the end of working life, i.e. until the age of 65 years. These results correspond with the results of previously published research (Pavlica et al., 2012; Kelly et al., 2008), and have a slightly higher value than the results of a population study conducted in Switzerland (Kyle et al.,2003). However, it should be pointed out that the above-mentioned study did not use a random sample of the population, and the fact that Switzerland, according to WHO, is the country with the lowest average BMI in Europe. On the other hand, the results of this study correspond to the results obtained in Eastern Europe (Meyer et al., 1995) where average BMI value for men aged 50-60 and 60-65 years was $27.5 \pm 3.95$ and $27.5 \pm 3.9 \mathrm{~kg} \cdot \mathrm{m}^{-2}$, respectively.

In relation to the prevalence of the body mass index, based on the obtained results, it can be argued that at the level of the overall sample, $1.4 \%$ of the subjects belong to the category of underweight, $47.9 \%$ have optimal weight, while 37.3 and $13.4 \%$ of persons are in categories of overweight and obese, respectively. In other words, the existence of an increasing share of overweight and obese people at the level of $51.7 \%$ among the working population of the Republic of Serbia has been determined. This fact is especially worrying it the context of the continuity of these findings, considering that earlier research has determined the percentage of these categories of the nutritional status of as much as 54\% (Ministry of Health of the Republic of Serbia, 2004). Still, it can be argued that even though the situation is alarming, the population of the Republic of Serbia is still far from an extreme distribution of the nutritional status that, for example, characterizes Mexican population in the United States of America where the obtained results indicate that as many as $72.4 \%$ of men and women are in the categories of overweight or obesity (Flegal et al., 2004). In relation to the stratification of the sample in relation to gender, it is evident that the percentage share of the categories of the nutritional status is significantly more favorable among women than among men. In this sense, $65.3 \%$ of the female participants belong to the category of optimal weight, $31.02 \%$ are overweight and obese categories and $3.6 \%$ are in the underweight category. On the other hand, only $0.2 \%$ of men belong to the underweight category, while 37.9 and $61.9 \%$ of men can be classified as overweight and obese, respectively. Among obese participants, a BMI growth trend in function of age has been estab- 
lished, which corresponds with the results of previous research (Rotar et al., 2016).

On the basis the above mentioned, it can be concluded that the working population of the Republic of Serbia, on a general level and in relation to gender, is characterized by a noticeably increased share of overweight and obesity and thus the obtained results do not differ significantly from other European countries (WHO, 2014). This fact puts the Republic of Serbia among other countries that are practically facing the problems of reduced physical and working capacity of the population and the increased frequency of pathological examples (Đorđević-Nikić et al., 2013) due to the problem of overweight and obesity of epidemiological proportions with the tendency of further growth.

\section{CONCLUSION}

In relation to the values of mean BMI determined at the level of the overall sample, it can be argued that the working population of the Republic of Serbia is characterized by the value of the given index at the level of $25.63 \pm 0.21 \mathrm{~kg} \cdot \mathrm{m}^{-2}$, while at the level of male and female test groups BMI mean value is at the level of $26.53 \pm 4.07$ and $24.07 \pm 5.09 \mathrm{~kg} \cdot \mathrm{m}^{-2}$, respectively. In relation to the prevalence, on the basis of the obtained results, it was determined that at the level of the overall sample, $1.4 \%$ of the subjects are in the category of underweight, $47.9 \%$ of the subjects have optimal weight, while the share of overweight and obese persons is 37.3 and $13.4 \%$, respectively. Regarding the female subsample, $65.3 \%$ of participants belong to the category of optimal weight, $18.7 \%$ to the category of overweight, $12.5 \%$ to the category of obesity and $3.6 \%$ to the underweight category. Regarding the male subsample, the percentage of underweight participants at the level of $0.2 \%$ was determined, while in the categories of normal nutrition, overweight, and obesity, there were $37.9,48.0$ and $13.9 \%$ of subjects, respectively.

The highest prevalence of overweight and obesity was determined at the age of 60-65 years. At the level of male subsample, there were $45.2 \%$ of pre-obese and $26.0 \%$ obese participants, respectively. The overall prevalence of people with increased body weight was $71.2 \%$. In relation to the female subsample, the prevalence of overweight was at the level of $36.8 \%$, while obesity was as high as $41.4 \%$. The overall prevalence of weight gain in women was $78.2 \%$.

On the basis of the defined models of the nutrition status in relation to age, it was found that for the male subsample the established BMI growth constant is $0.0904 \mathrm{~kg} \cdot \mathrm{m}^{-2}$, that is $90.4 \mathrm{~g} \cdot \mathrm{m}^{-2}$ per year of life, while for the female subsample growth constant is at the level of $0.1767 \mathrm{~kg} \cdot \mathrm{m}^{-2}$, that is $176.7 \mathrm{~g} \cdot \mathrm{m}^{2}$ per year of life.

The results of this study indicate that the Republic of Serbia follows the global trend of increase in mean $\mathrm{BMI}$ as an indicator of the nutritional status of the population, i.e. it can be concluded that on a general level as well as in relation to gender, the working population of the Republic of Serbia is characterized by an increased percentage share of overweight and obesity.

\section{ACKNOWLEDGMENT}

This paper is part of the project „Effects of applied physical activity on the locomotor, metabolic, psychosocial and educational status of the population of the Republic of Serbia", number III47015, financed by the Ministry of Education, Science and Technological Development of the Republic of Serbia - scientific projects, 2011-2018 cycle. 


\section{REFERENCES}

1. Bruffaerts, R., Demyttenaere, K., Vilagut, G., Martinez, M., Bonnewyn, A., De Graaf, R., Haro, J.M., Bernert, S., Angermeyer, M.C., Brugha, T., Roick, C., Alonso, J. (2008). The relation between body mass index, mental health, and functional disability: a European population perspective. Canadian Journal of Psychiatry, 53(10), 679 - 688.

2. Bungum, T., Satterwhite M., Jackson, A.W., Morrow Jr, J.R. (2003). The relationship of body mass index, medical cost, and job absenteeism. American Journal of Health Behaviour, 27(4), 456 - 462.

3. Gába, A., Kapuš, O., Cuberek, R., \& Botek, M. (2015). Comparison of multi- and single-frequency bioelectrical impedance analysis with dual-energy X-ray absorptiometry for assessment of body composition in postmenopausal women: effects of body mass index and accelerometer-determined physical activity. Journal of Human Nutrition and Dietetics, 28, 390 - 400.

4. Đorđević-Nikić,M., Dopsaj, M., Rakić, S., Subošić, D., Prebeg, G., Macura, M., Mlađan, D., Kekić, D. (2013). Morfološki model populacije radno aktivnih žena Beograda meren metodom električne multikanalne bioimpendance: Pilot istraživanje. [Morphological model of the population of working-age women in Belgrade measured using electrical multichannel bioimpedance model: Pilot study. In serbian]. Physical Culture 67(2), 103 - 112.

5. Ilić, D. (Ed) (2016). Zdravstveno-statistički godišnjak Republike Srbije 2015. [Health and Statistical Yearbook of the Republic of Serbia 2015. In Serbian]. Institut za javno zdravlje Srbije "Dr Milan Jovanović Batut" Beograd, Elit Medika.

6. Jackson, J.E., Doescher, M.P., Jerant, A.F., \& Hart, G.L. (2005). A national study of obesity prevalence and trends by type of rural county. The Journal of Rural Health, 21(2), 140 - 148.

7. Katzmarzyk, P.T., \& Janssen, I. (2004). The economic costs associated with physical inactivity and obesity in Canada: an update. Canadian Journal of Applied Physiology, 29(1), 90 - 115.

8. Kelly, T., Yang, W., Chen, C-S., Reynolds, K., \& He, J. (2008). Global burden of obesity in 2005 and projections to 2030. International Journal of Obesity, 32, 1431 - 1437.

9. Krishna, A., Razak, F., Lebel, A., Smith, G.D., \& Subramanian, S.V. (2015). Trends in group inequalities and interindividual inequalities in BMI in the United States, 1993-2012. American Journal of Clinical Nutrition 101, 598 - 605 .
10. Kyle, U. G., Schutz, Y., Dupertuis, Y. M., \& Pichard, C. (2003). Body composition interpretation. Contributions of the fat-free mass index and the body fat mass index. Nutrition, 19(7-8), 597-604.

11. Lakerveld, J., Rebah, M.B., Mackenbach, J.D., Charreire, H., Compemolle, S., Glonti, K., Bardos, H., Rutter, H., De Bourdeadhuji, I., Brug, J., Oppert, J-M. (2015). Obesity-related behaviors and BMI in five urban regions across Europe: sampling design and results from the SPOTLIGHT cross-sectional study. BMJ Open 5(10):e008505.

12. Meyer, H. E., Falch, J. A., O’Neill, T., Tverdal, A., \& Varlow, J. (1995). Height and body mass index in Oslo, Norway, compared to other regions of Europe: Do they explain differences in the incidence of hip fracture? Bone, 17(4), 347-350.

13. Ministarstvo zdravlja Republike Srbije, (2004). Nacionalni vodič za lekare u primarnoj zdravstvenoj zaštiti. Gojaznost. [National Guide to Physicians in Primary Health Care. Obesity. In Serbian]. Beograd: Medicinski fakultet Univerziteta u Beogradu, Centar za izdavačku, bibliotečku i informacionu delatnost.

14. NCD Risk Factor Collaboration (NCD-RisC) (2016). Trends in adult body-mass index in 200 countries from 1975 to 2014: a pooled analysis of 1698 population-based measurement studies with 19.2 million participants. Lancet, 387(10026), 1377-1396.

15. Pavlica, T., Božić-Krstić, V., Rakić, R., i Saka, D. (2012). Prevalencija prekomerne telesne mase i gojaznosti kod odrasle seoske populacije Bačke i Banata. [Prevalence of overweight and obesity in adult rural population of Backa and Banat. In Serbian]. Vojnosanitetski Pregled, 69(10), 833 - 839.

16. Pavlica, T., Božić-Krstić, V., Rakić, R., i Srdić, B. (2010). Uhranjenost i distribucija masnog tkiva kod zdravih odraslih osoba u nekim mestima centralnog Banata. [ Nutrition and distribution of fatty tissue in healthy adults in some places in central Banat In Serbian.]. Medicinski Pregled, LXIII (1-2), 21 - 26.

17. Perić, D. (2003). Statistika primenjenau sportu $i$ fizičkom vaspitanju. [Statistics applied in sports and physical education.In Serbian]. Beograd: Fakultet sporta i fizičkog vaspitanja. 
18. Peytremann-Bridevaux, I., Faeh D., Santos-Eggimann, B. (2007). Prevalence of overweight and obesity in rural and urban settings of 10 European countries. Preventive Medicine, 44, 442 - 446.

19. Prentice, M.A., \& Jebb, A.S. (2001). Beyond body mass index. Obesity Reviews, 2, 141 - 147.

20. Rotar, O., Boyarinova, M., Orlov, A., Solntsev, V., Zhernakova, Y., Shalnova, S., Deev, A., Konradi, A., Baranova, E., Chazova, I., Boytsov, S. \& Shlyakhto, E. (2016). Metabolically healthy obese and metabolically unhealthy non-obese phenotypes in a Russian population. European Journal of Epidemiology, 32(3), 251-254.

21. Finucane, M., Stevens, G.A., Cowan, M.J., Danaei, D., Lin, J.K., Paciorek, C.J., Singh, G.M., Gutierez, H.R., Lu, Y., Bahalim, A.D., Farzadfar, F., Riley, L.M., Ezzati, M. (2011). National, regional, and global trends in body-mass index since 1980: systematic analysis of health examination surveys and epidemiological studies with 960 countryyears and 9.1 million participants. Lancet, 377, 557-567.
22. Flegal, K. M., Ogden, C. L. \&. Carroll, M. D. (2004). Prevalence and trends in overweight in Mexican-American adults and children. Nutrition Reviews, 62(7), 144-148.

23. Flegal, K.M., Carroll, M.D., Kit, B.K., Ogden, C.L. (2012). Prevalence of obesity and trends in the distribution of body mass index among US adults, 1999-2010. Journal of American Medical Association, 307(5), 491 - 497.

24. Weisell, R.C. (2002). Body mass index as an indicator of obesity. Asia Pacific Journal of Clinical Nutrition 11(Suppl), S681 - S684.

25. World Health Organization. Global status report on noncommunicable diseases (2014). Attaining the nine global noncommunicable diseases targets; a shared responsibility. Geneva: WHO.

26. World Health Organization. Western Pacific Region. (2000). The Asia-Pacific perspective: Redefining Obesity and its treatment. International Obesity Task Force.

\title{
IMC: ANÁLISIS DE LOS INDICADORES DE POBLACIÓN EN FUNCIÓN DEL SEXO Y DE LA EDAD EN LA POBLACIÓN ACTIVA DE LA REPÚBLICA DE SERBIA
}

\begin{abstract}
Extracto
El objetivo del presente trabajo es la apreciación general de los indicadores de estado nutricional de la población activa de la República de Serbia, definida sobre la base del valor del Índice de masa corporal (IMC). La muestra estaba compuesta de 7125 examinados activos, de los que 4525 (63,51\%) personas del sexo masculino y 2600 (36,49\%) personas del sexo femenino. Los examinados territorialmente pertenecían a las regiones de Voivodina, ciudad de Belgrado, Serbia central, occidental, del sur y oriental. Los valores promedios de IMC en nivel de submuestras de hombres y de mujeres eran $26.53 \pm 4.07$ y $24.07 \pm 5.09 \mathrm{~kg} / \mathrm{m}^{2}$ respectivamente. Sobre la base de los resultados obtenidos se estableció la existencia de una diferencia de IMC estadísticamente significativa en el nivel general, tanto entre los sexos ( $\mathrm{F}=58.412$, $\mathrm{p}<0.000)$, como en relación con la categoría de edad de los examinados $(\mathrm{F}=268.885, \mathrm{p}<0.001)$, como también la interacción de los factores dados $(\mathrm{F}=18.203 . \mathrm{p}<0.000)$. En relación con la prevalencia, para la submuestra de mujeres, en la categoría de normalmente nutridas estaban los $65.3 \%$ de las examinadas, en la categoría de las excesiva nutridas los 18,7\%, es decir $12.5 \%$ obesas, mientras que a la categoría de subnutridas pertenecían los 3.6\% de las examinadas. Entre los hombres se estableció la prevalencia de subnutrición en nivel de los 0,2\%, mientras que a las categorías de la nutrición normal, es decir excesiva y a la obesidad pertenecían los 37.9, 48.0 и $13.9 \%$ de los examinados respectivamente. La mayor prevalencia de la nutrición excesiva y de la obesidad se estableció en la edad de 60-65 años, donde en el nivel de submuestra de hombres hay los $45.2 \%$ de los examinados preobesos y los $26.0 \%$ de los obesos. En relaciòn con la muestra de mujeres se estaleció la prevalencia de la nutrición excesiva en el nivel de los 36.8\%, mientras que hay incluso los $41.4 \%$ de las obesas. Sobre la base de los modelos definidos de las tendecias de cambio de estatus de nutrición en funciòn de la edad, se estableció que para la submuestra de los hombres la constante establecida del aumento de nivel de nutrición asciende a $0.0904 \mathrm{~kg} / \mathrm{m}^{2}$, es decir $90.4 \mathrm{~g} / \mathrm{m}^{-2}$ por un año de vida, mientras que entre las mujeres está en nivel de $0.1767 \mathrm{~kg} / \mathrm{m}^{-2}$, es decir $176.7 \mathrm{~g} / \mathrm{M}^{-2}$ por un año de vida.
\end{abstract}

Palabras claves: NIVEL DE NUTRICIÓN / PREVALENCIA DE OBESIDAD / SEXO / EDAD / TENDENCIA DE CAMBIO 


\title{
БМИ: АНАЛИЗА ПОПУЛАЦИОНИХ ПОКАЗАТЕЉА У ФУНКЦИЈИ ПОЛА И УЗРАСТА КОД РАДНО АКТИВНИХ СТАНОВНИКА РЕПУБЛИКЕ СРБИЈЕ
}

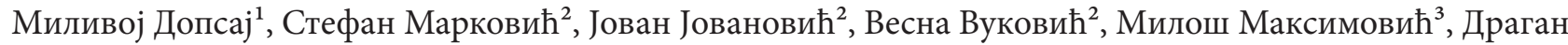 \\ Миљуш ${ }^{4}$, Милена С. Томанић ${ }^{3}$, Здравко Аничић $^{2}$, Лазар Д. Томић ${ }^{1}$, Александар Станковић ${ }^{2}$ \\ ${ }^{1}$ Универзитет у Београду, Факултет спорта и физичког васпитања \\ 2 Универзитет у Београду, Факултет спорта и физичког васпитања, студент ДАС \\ ${ }^{3}$ Универзитет у Београду, Медицински факултет, Институт за хигијену и медицинску екологију \\ ${ }^{4}$ Институт за јавно здравље „Др Милан Јовановић Батут“ Београд
}

\begin{abstract}
Сажетак
Циљ овог рада је сагледавање популационих показатеља ухрањености запосленог становништва Републике Србије, дефинисане на основу вредности Индекса телесне масе (БМИ). Узорак је сачињавало укупно 7125 радно активних испитаника, од чега 4525 (63.51\%) особа мушког пола и 2600 (36.49\%) особа женског пола. Испитаници су територијално припадали регионима Војводине, града Београда, Централне, Западне, Јужне и Источне Србије. Просечне вредности БМИ на нивоу субузорака мушкараца и жена су биле $26.53 \pm 4.07$ и $24.07 \pm 5.09$ кг· $\mathrm{M}^{-2}$, респективно. На основу добијених резултата утврђено је постојање статистички значајних разлика БМИ на генералном нивоу, како између полова $(\mathrm{F}=58.412, \mathrm{p}<0.000)$, тако и у односу на узрасну категорију испитаника $(\mathrm{F}=268.885, \mathrm{p}<0.001)$, те интеракцију комбинације датих фактора $(\mathrm{F}=18.203$. $\mathrm{p}<0.000)$. У односу на преваленцију, за субузорак жена, у категорији нормално ухрањених било је $65.3 \%$ испитаница, у категорији прекомерне ухрањености $18.7 \%$, односно гојазности $12.5 \%$, док је категорији потхрањености припадало $3.6 \%$ испитаница. Код мушкараца је утврђена преваленција потхрањености на нивоу $0.2 \%$, док је категоријама нормалне, односно прекомерне ухрањености и гојазности припадало $37.9,48.0$ и $13.9 \%$ испитаника, респективно. Највећа преваленција прекомерне ухрањености и гојазности утврђена је на узрасту од 60-65 година, где на нивоу субузорка мушкараца има $45.2 \%$ предгојазних и $26.0 \%$ гојазних испитаника. У односу на узорак жена утврђена је преваленца прекомерне ухрањености на нивоу $36.8 \%$, док је гојазних чак 41.4\%. На основу дефинисаних модела трендова промене статуса ухрањености у функцији узраста утврђено је да за субузорак мушкараца утврђена константа прираста нивоа ухрањености износи 0.0904 кг $\cdot \mathrm{M}^{-2}$, односно $90.4 \mathrm{r} \cdot \mathrm{M}^{-2}$ по години живота, док је код жена на нивоу 0.1767 кг $\mathrm{M}^{-2}$, односно 176.7 г $\cdot \mathrm{M}^{-2}$ по години живота.
\end{abstract}

КљУчне речи: НИВО УХРАњЕНОСТИ / ПРЕВАЛЕНЦИЈА ГОЈАЗНОСТИ / ПОЛ / УЗРАСТ / ТРЕНД ПРОМЕНЕ

\section{УВОД}

Прекомерна ухрањеност и гојазност не само да утичу на свакодневни живот, већ се у значајној мери одражавају на радну способност и продуктивност становништва (Bruffaerts et al., 2008). Особе чија тежина превазилази просечне вредности карактеристичне за старост и пол, за $12 \%$ више одсуствују са посла у односу на нормално ухрањене. Код гојазних је ситуација алармантнија. Радно одсуство досеже чак $30 \%$ (Bungum et al., 2003) изазивајући пад продуктивности (Katzmarzyk \& Janssen, 2004), док се трошкови лечења и здравствене заштите значајно повећавају у односу на оне са нормалним индексом телесне масе (Bungum et al., 2003; Jackson et al., 2005).

Индекс телесне масе (енг. Body Mass Index - БМИ) је широко прихваћен морфолошко- 
Допсај М., и сар., БМИ: Анализа популационих показатеља..., ФИЗИЧКА КУЛТУРА 2018; 72 (2): 148-160

нутритивни показатељ ухрањености, а Светска здравствена организација (С3О) сматра га стандардом за дефинисање нивоа гојазности (WHO, 2000). Иако БМИ, као универзални индикатор стања ухрањености, није довољно дискриминативан када су у питању расне разлике или одређене категорије испитаника, попут деце, спортиста, особа запослених у војнобезбедоносним структурама и сл. (Prentice \& Jebb, 2001), БМИ остаје у употреби као једноставан, неинвазиван и поуздан параметар за процену стања и праћење тенденција ухрањености и гојазности најшире популације (ЂорђевићНикић и сар., 2013).

Тренд пораста прекомерно ухрањених и гојазних људи све је израженији (Finucane et al., 2011). На глобалном нивоу, гојазност је у последњих четрдесет година порасла за 7.6\% код мушкараца и за 8.5\% код жена (NCD Risk Factor Collaboration, 2016). Процењује се да је 2008. године на свету било скоро милијарду и по људи са БМИ већим од 25 кг·м ${ }^{-2}$ (Finucane et al., 2011). Повећање телесне масе изнад граница просека за узраст и пол није више искључиво проблем развијених држава. Земље у развоју једнако су погођене негативним променама (Weisell, 2002; Kelly et al., 2008), а значајне разлике примећуjу се између урбаних и руралних средина (Jackson et al., 2005).

Опсежним истраживањем које је обухватило податке о нешто више од девет милиона испитаника, утврђено је да највише просечне вредности БМИ имају мушкарци (33.9 кг· $\left.\mathrm{M}^{-2}\right)$ и жене $\left(35.0\right.$ кг· $\left.\mathrm{M}^{-2}\right)$ из подручја Океаније (WHO, 2000; Finucane et al., 2011). У Субсахарској Африци, источној, северној и северо-источној Азији, просечне вредности БМИ ниже од 21.5 кг·м ${ }^{-2}$ карактеристичне су за оба пола (Finucane et al., 2011). Када су у питању развијене земље, Сједињене Америчке Државе предњаче по високим вредностима БМИ у односу на остатак света (Finucane et al., 2011). Ипак, аутори истичу битне разлике код група различитог етничког порекла и социо-економског статуса (Flegal et al., 2004; Krishna et al., 2015). Највиши просечни БМИ код мушкараца регистрован у Северној Америци

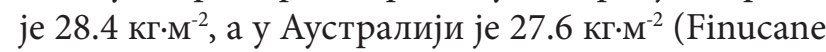
et al., 2011). Када су жене у питању, на глобалном нивоу примећен је прираст телесне масе за 0.5 кг· $\mathrm{M}^{-2}$ по декади. Повећање БМИ је најизраженије код жена Океаније, а за њима следе жене Латинске Америке (Finucane et al., 2011).

Супротно неким налазима Џексона и сарадника (2005), истраживање преваленције гојазности у десет европских земаља показало је да не постоје значајне разлике у просечним вредностима БМИ становника руралних и урбаних средина, изузев у Грчкој (Peytremann-Bridevaux et al., 2007). Разлози за варијабилност БМИ би се могли наћи у социоекономском статусу и преовлађујућем животном стилу становника (Lakerveld et al., 2015). Највише прекомерно ухрањених Европљана са индексом телесне масе између 25.0 кг м $^{-2}$ и 29.9 кг· $\mathrm{M}^{-2}$ живи у Грчкој (48.1\%) и Шпанији (45.4\%), а најмање у Швајцарској (37.9\%). Земље са највећим бројем гојазних становника чији БМИ износи $\geq 30.0$ кг·- ${ }^{-}$ ${ }^{2}$ су Шпанија (24.0\%), Грчка (20.8\%) и Аустрија (19.9\%) (Peytremann-Bridevaux et al., 2007).

Постојећи подаци указују да и у Србији код популације одраслих постоје високе просечне вредности БМИ. Војводина је лоцирана као подручје са највећом преваленцом прекомерне ухрањености (33.5\%) и гојазности (23.0\%) (Pavlica i sar., 2010), а оверезултате потврђује и истраживање спроведено са одраслом популацијом у Бачкој и Банату, где је утврђена процентуална заступљеност прекомерне ухрањености на нивоу $45.1 \%$ код мушкараца и 32.0\% код жена, док су за гојазност забележене вредности од 21.2\% код испитаника мушког и $17.7 \%$ код женског пола (Pavlica i sar., 2012). Да постоје разлике у индексу телесне масе у зависности од региона, потврђују подаци добијени на узорку радно активних жена са територије Београда, где је преко 55\% испитаница припадало нормално ухрањеним, $30 \%$ зони предгојазних, а 10\% је било гојазно. Треба нагласити да је ово истраживање рађено на ограниченом узорку од 109 испитаница, од којих је скоро 69\% било физички активно (ЂорђевићНикић и сар., 2013).

Због потреба континуираног праћења статуса ухрањености становништва и ради прецизнијег дефинисања анализе стања актуелних популационих показатеља, потребно је обезбедити валидне и референтне податке. Ово се нарочито односи на период почетка трећег миленијума, када је утврђена значајна негативна промена преваленције непожељних категорија, односно предгојазних и гојазних особа. У том смислу, примарни циљ ове студије је утврђивање 
популационих показатеља ухрањености код радно активног становништва Републике Србије (РС) у функцији пола и узраста.

\section{МЕТОД РАДА}

Ово истраживање је неексперименталног и трансверзалног карактера. У односу на врсту мерења, примењена је метода лабораторијског тестирања.

\section{Узорак}

Узорак је сачињавало укупно 7125 радно активнихиспитаника, просечнихгодина $32.3 \pm 10.4$, међу којима је било 4525 (63.51\%) особа мушког пола, старосног доба $32.9 \pm 11.3$ година, и 2600 (36.49\%) испитаница, просечне старости 32.0土9.8 година. Испитаници су подељени на субузорке у односу на критеријум пола и узраста; дакле било је по пет субузорака мушког и женског пола. У оквиру укупног узорка, највише испитаника је било из групе узраста од 18-30 година (45.68\%), док је најмањи удео особа узраста између 60-65 година (1.94\%). Основни дескриптивни показатељи за субузорак мушкараца су били $\mathrm{TB}=181.61 \pm 6.76$ цм и $\mathrm{TM}=87.68 \pm 14.73$ кг, док су за субузорак жена просечна телесна висина и телесна маса на нивоу $\mathrm{TB}=168.07 \pm 6.70$ цм и $\mathrm{TM}=67.83 \pm 13.88$ кг. Сви испитаници су становници Републике Србије, са територијалном структуром испитаника из Војводине, града Београда, као и територијалних региона Централне, Западне, Јужне и Источне Србије. На нивоу целокупног узорка испитаници су били становници 62 града, уз следећу процентуалну заступљеност по регионима: Београд и околина $25.17 \%$, Војводина $29.77 \%$, Централна Србија 17.88\%, Јужна и Источна Србија $12.58 \%$ и Западна Србија 14.60\%, чиме су обезбеђени методолошки услови прихватања резултата на нивоу популационих студија.

Сви испитаници су били упознати са циљем истраживања и добровољно су пристали да учествују у истом. Испитивање је реализовано у складу са постулатима Хелсиншке декларације и уз одобрење Етичке комисије Факултета спорта и физичког васпитања, Универзитета у Београду.

\section{Методе мерења}

Сва мерења извршена су у периоду 2011-2018. годинеуМетодичко-истраживачкојлабораторији (МИЛ) Факултета спорта и физичког васпитања, Универзитета у Београду, као и у Институту за хигијену и медицинску екологију Медицинског факултета Универзитета у Београду. Мерења су реализована стандардизованом процедуром, применом методе електричне мултиканалне (1, 5, 50, 250, 500, $1000 \mathrm{kHz}$ ) биоимпеданце (МБИ), помоћу анализатора телесне структуре најновије генерације - InBody 720 (Biospace Co., Ltd, Seoul, Korea).

Мерење телесне висине (ТВ) вршено је антропометром (GPM, Swissmade) у јутарњим часовима (08:00-10:00), док је мерење телесне масе реализовано на поменутом апарату „InBody 720“ у складу са стандардизованом процедуром описаном раније (Gaba et al., 2015). Мерење ТВ и телесног статуса је реализовано од стране искусних мериоца.

Субузорак узрасних категорија је дефинисан према препорукама С3O, са корекцијом за прву узрасну групу, и то у односу на следећих 5 узрасних категорија: 18-29.9; 30-39.9; 40-49.9; 5059.9; 60-65.0 година.

\section{Варијабле}

Опште прихваћен показатељ ухрањености, односно мера статуса ухрањености тела је индекс телесне масе (БМИ-Body Mass Index). БМИ представља однос телесне масе (ТМ) и квадрата телесне

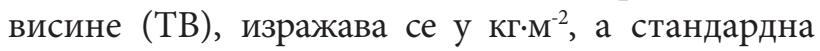
WHO класификација је: потхрањеност БМИ<18.5 кг $\cdot \mathrm{M}^{-2}$; нормална ухрањеност БМИ=18.5-24.99 кг· $\mathrm{M}^{-}$ 2; предгојазност БМИ=25.00-29.99 кг·м-2; гојазност (класа 1) БМИ=30.00-34.99 кг·м ${ }^{-2}$; гојазност (класа 2) БМИ=35.00-39.99 кг·м ${ }^{-2}$; гојазност (класа 3) БМИ $\geq 40.00 \kappa \Gamma \cdot \mathrm{M}^{-2}(\mathrm{WHO}, 2000)$.

\section{Статистичка анализа}

Сви подаци су анализирани применом метода дескриптивне и аналитичке статистике. За испитивану варијаблу, у функцији укупног узорка и субузорака у односу на пол и узраст, израчунате су све релевантне мере централне тенденције и дисперзије података и то: MEAN, SD, MIN, MAX, KURT, SKEW, $\mathrm{SE}_{\mathrm{M}}$, CV\%. Нормалност дистрибуције података је утврђена применом стандардизованог 
непараметријског теста „Колмогоров-Смирнов“ (K-S Z). Разлике на генералном нивоу, у односу на пол и узраст испитаника и комбинацију ова два фактора, испитиване су применом факторске анализе варијансе (Factorial ANOVA). Парцијалне разлике између дефинисаних субгрупа утврђене су применом постхок тестова уз коришћење Бонферони корекције. Анализа података извршена је применом софтверских пакета „Excel 2013“ и „IBM SPSS v.23“, док је ниво значајности био дефинисан за вероватноћу од 95\%, односно $\mathrm{p} \leq 0.05$.

\section{РЕЗУЛТАТИ}

Табела 1. Основни дескриптивни статистици испитиване варијабле у функцији субузорака

\begin{tabular}{|c|c|c|c|c|c|c|c|c|c|c|c|c|}
\hline \multicolumn{13}{|c|}{ Дескриптивни статистици за варијаблу БМИ } \\
\hline Група & $\mathbf{N}$ & $\begin{array}{c}\text { Mean } \\
\left(\mathrm{kg} \cdot \mathrm{m}^{-2}\right)\end{array}$ & $\begin{array}{c}\text { Std. Error } \\
\text { Mean } \\
\left(\mathbf{k g} \cdot \mathbf{m}^{-2}\right)\end{array}$ & $\begin{array}{c}\text { Std. } \\
\text { Error } \\
\text { Mean \% }\end{array}$ & $\begin{array}{c}\text { SD } \\
\left(\mathbf{k g} \cdot \mathbf{m}^{-2}\right)\end{array}$ & $\mathrm{cV} \%$ & $\underset{\left(\mathbf{k g} \cdot \mathbf{m}^{-2}\right)}{\operatorname{Min}}$ & $\underset{\left(\mathbf{k g} \cdot \mathbf{m}^{-2}\right)}{\operatorname{Max}}$ & Skew. & Kurt. & $\begin{array}{c}\mathrm{K}-\mathrm{S} \\
\mathrm{Z}\end{array}$ & $\begin{array}{c}\text { K-S } \\
\text { (p value) }\end{array}$ \\
\hline Укупно & 7125 & 25.63 & 0.05 & 0.21 & 4.62 & 18.03 & 14.43 & 63.47 & 1.42 & 4.52 & 0.072 & 0.000 \\
\hline Жене & 2600 & 24.07 & 0.10 & 0.41 & 5.09 & 21.13 & 14.43 & 63.47 & 1.81 & 5.54 & 0.127 & 0.000 \\
\hline Жене, 18-30 год. & 1178 & 22.18 & 0.11 & 0.50 & 3.80 & 17.13 & 14.43 & 48.63 & 2.22 & 7.04 & 0.160 & 0.000 \\
\hline Жене, 30-40 год. & 735 & 24.64 & 0.20 & 0.81 & 5.38 & 21.84 & 16.57 & 49.64 & 1.56 & 2.87 & 0.141 & 0.000 \\
\hline Жене, 40-50 год. & 430 & 25.69 & 0.23 & 0.88 & 4.67 & 18.17 & 16.57 & 56.28 & 1.76 & 6.93 & 0.114 & 0.000 \\
\hline Жене, 50-60 год. & 181 & 27.48 & 0.37 & 1.35 & 4.99 & 18.17 & 17.15 & 41.69 & 0.49 & -0.15 & 0.060 & 0.200 \\
\hline Жене, 60-65 год. & 76 & 30.57 & 0.86 & 2.82 & 7.53 & 24.62 & 21.52 & 63.47 & 2.33 & 8.05 & 0.141 & 0.001 \\
\hline Мушкарци & 4525 & 26.53 & 0.06 & 0.23 & 4.07 & 15.34 & 15.89 & 52.90 & 1.64 & 5.30 & 0.091 & 0.000 \\
\hline Мушкарци, 18-30 год. & 2077 & 24.91 & 0.07 & 0.29 & 3.29 & 13.22 & 15.89 & 51.39 & 2.19 & 10.37 & 0.100 & 0.000 \\
\hline Мушкарци, 30-40 год. & 1498 & 27.74 & 0.11 & 0.40 & 4.26 & 15.34 & 18.59 & 52.90 & 1.76 & 5.79 & 0.110 & 0.000 \\
\hline Мушкарци, 40-50 год. & 704 & 28.14 & 0.15 & 0.55 & 4.07 & 14.48 & 18.65 & 49.16 & 1.25 & 3.23 & 0.091 & 0.000 \\
\hline Мушкарци, 50-60 год. & 184 & 28.01 & 0.24 & 0.86 & 3.25 & 11.61 & 19.57 & 40.26 & 1.10 & 2.40 & 0.129 & 0.000 \\
\hline Мушкарци, 60-65 год. & 62 & 28.62 & 0.64 & 2.24 & 5.04 & 17.61 & 20.99 & 42.77 & 1.04 & 0.70 & 0.140 & 0.004 \\
\hline
\end{tabular}

На основу презентованих резултата (Табела 1) може се тврдити да су подаци варијабла БМИ хомогени, коефицијент варијације износи у распону од $11.61 \%$, за вредности БМИ субузорка мушкараца 50-60 год., до 24.62\%, за субузорак жена 60-65 год. Такође, потребно је нагласити да је у односу на смер закривљености криве код свих субгрупа утврђен асиметричан, позитивно усмерен, облик дистрибуције података
(SKEWNESS у распону од 0.49 за субузорак жена 50-60 година до 2.33 за субузорак жена 60-65 година). У односу на облик дистрибуције по спљоштености, утврђена је варијација у релативно широким границама. Вредности мере спљоштености дистрибуције крећу се у распону од -0.15 за субузорак жена 50-60 година, до 10.37 за субузорак мушкараца 18-30 година. 
Допсај М., и сар., БМИ: Анализа популационих показатеља..., ФИЗИЧКА КУлТУРА 2018; 72 (2): 148 -160

Табела 2. Резултати факторске анализе варијансе за испитивану варијаблу БМИ у односу на пол и узраст испитаника

Резултати Факторске анализе варијансе у односу на пол и узраст испитаника

\begin{tabular}{lccccccc}
\hline Зависна варијабла: БМИ & & & & & & & \\
Извор & $\begin{array}{c}\text { Type III Sum of } \\
\text { Squares }\end{array}$ & df & Mean Square & F & Sig. & $\begin{array}{c}\text { Partial Eta } \\
\text { Squared }\end{array}$ & $\begin{array}{c}\text { Observed } \\
\text { Power }\end{array}$ \\
\hline Пол & 994.418 & 1.000 & 994.418 & 58.412 & 0.000 & 0.008 & 0.131 \\
Узраст & 18310.233 & 4.000 & 4577.558 & 268.885 & 0.000 & 0.000 \\
Пол• Узраст & 1239.555 & 4.000 & 309.889 & 18.203 & 0.000 & 0.010 & 1.000 \\
\hline
\end{tabular}

Резултати факторске анализе варијансе (Табела 2) су показали да постоји статистички значајна разлика вредности БМИ у односу на пол

$(\mathrm{F}=58.412, \mathrm{p}<0.000)$, у односу на узрасне категорије $(\mathrm{F}=268.885, \mathrm{p}<0.001)$, као и да постоји интеракција фактора „пол-узраст“ $(\mathrm{F}=18.203 . \mathrm{p}<0.000)$.

Табела 3. Парцијалне статистичке разлике између узрасних група у функцији пола

Парцијалне статистичке разлике између узрасних група у функцији пола

\begin{tabular}{|c|c|c|c|c|c|}
\hline \multicolumn{6}{|c|}{ Зависна варијабла: БМИ } \\
\hline Узраст & & & $\begin{array}{c}\text { Mean } \\
\text { Difference }\end{array}$ & Std. Error & Sig. \\
\hline $18-30$ & Жене & Мушкарци & -2.729 & 0.150 & 0.000 \\
\hline $30-40$ & Жене & Мушкарци & -3.103 & 0.186 & 0.000 \\
\hline $40-50$ & Жене & Мушкарци & -2.447 & 0.253 & 0.000 \\
\hline $50-60$ & Жене & Мушкарци & -0.533 & 0.432 & 0.217 \\
\hline $60-65$ & Жене & Мушкарци & 1.951 & 0.706 & 0.006 \\
\hline
\end{tabular}

Резултати серије постхок тестова - Бонферони (Табела 3) су показали да постоје статистички значајне разлике $(\mathrm{p}<0.001)$ у вредностима БМИ по полу четири узрасне категорије (18-30, 30-40,
40-50 и 60-65 година), док у случају испитаника старости 50-60 год. није утврђено постојање статистички значајних разлика $(\mathrm{p}=0.217)$. 


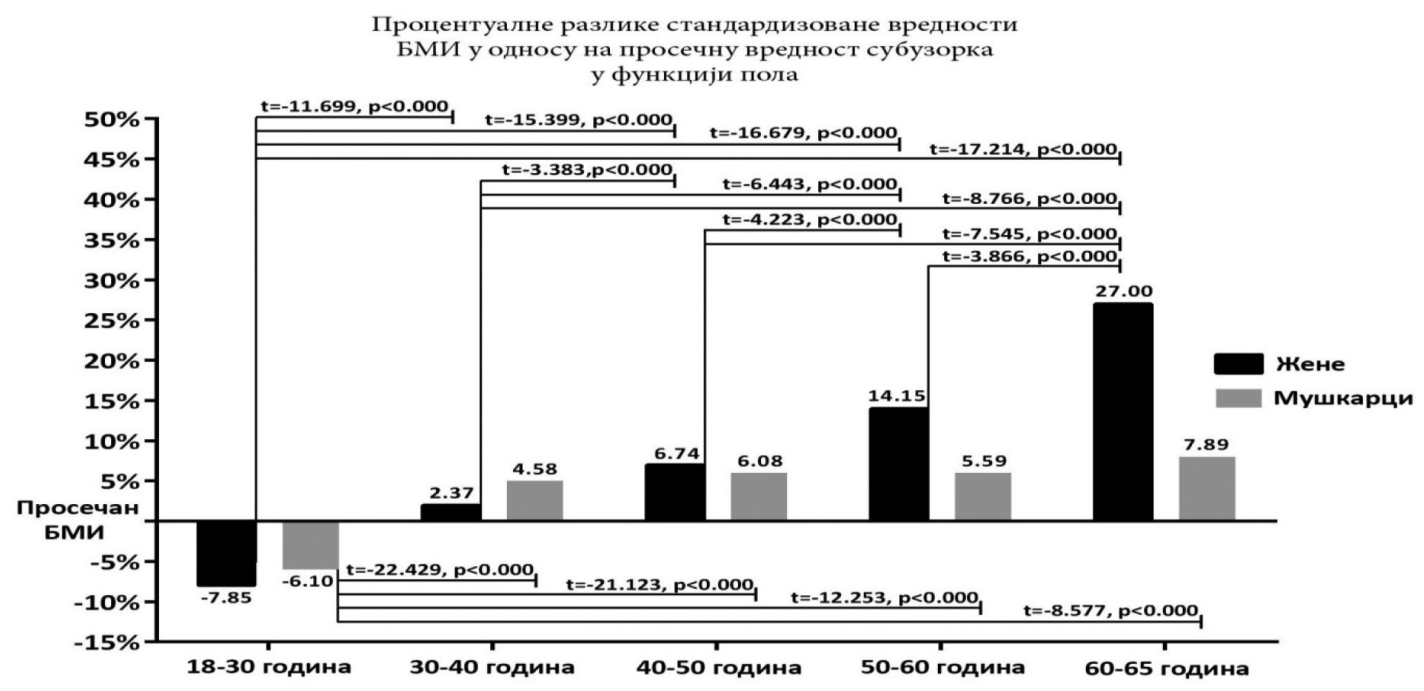

График 1. Процентуалне разлике стандардизоване вредности БМИ у односу на просечну вредност укупног субузорка у функцији пола са статистичком значајношћу разлика између појединачних узрасних група

График 1 приказује процентуалне разлике просечних вредности БМИ за дати субузорак у функцији пола према узрасним субгрупама, као и статистичку значајност разлика између узрасних група унутар субузорака мушкараца и жена. Код испитаника женског пола утврђено је постојање статистички значајних разлика $(\mathrm{p}<0.000)$ између свих узрасних група, а када су у питању испитаници мушког пола, једино се узрасна група 18-30 год. статистички значајно разликује од осталих $(\mathrm{p}<0.000)$.

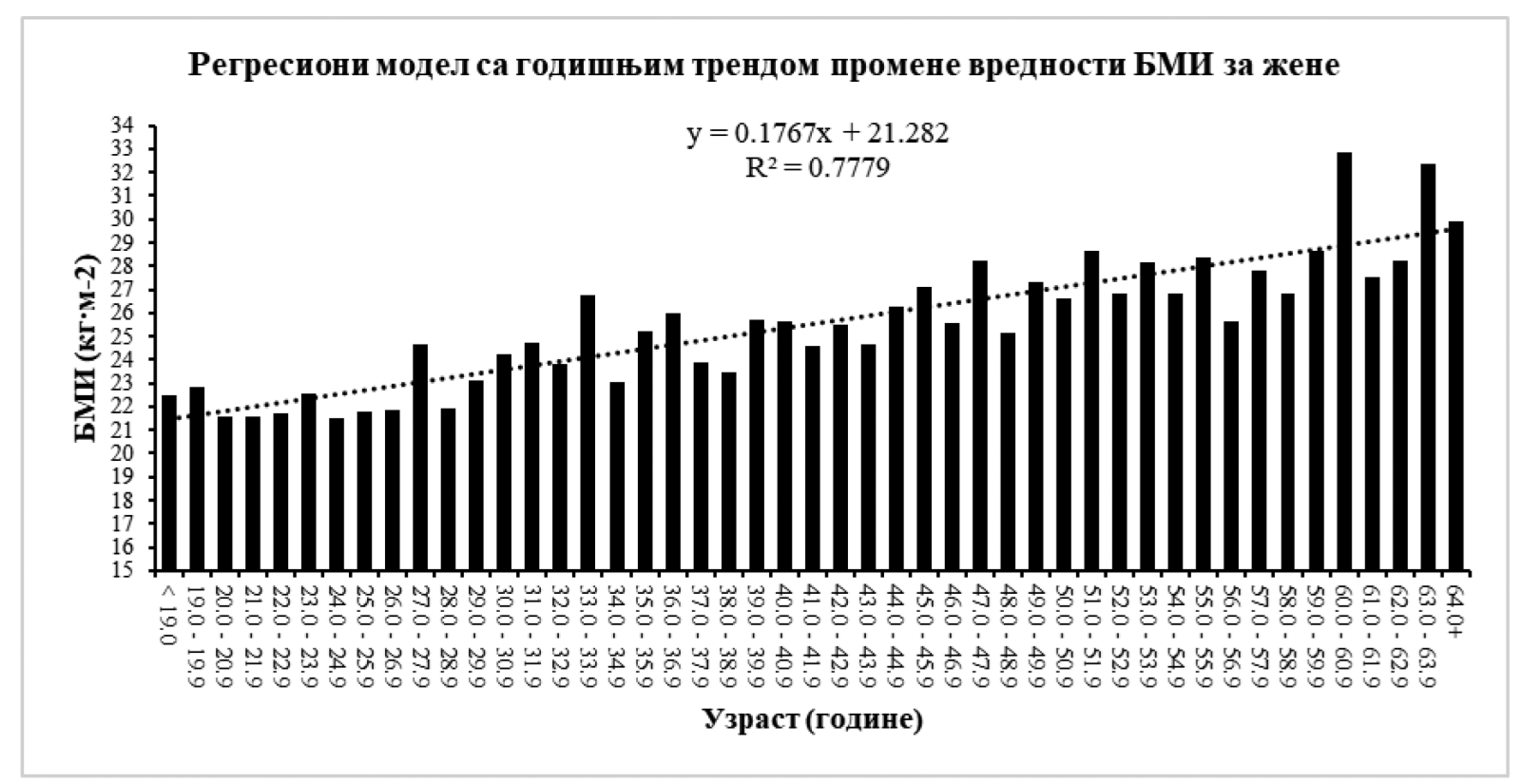

График 2. Регресиони модел са трендом промене вредности БМИ за субузорак радно способних жена 
На Графицима 2 и 3 приказани су модели зависности промене БМИ у функцији старости испитаника. На основу резултата може се тврдити да радно способне мушкарце, на генералном нивоу, карактеришу више вредности БМИ у односу на жене, при чему је прираст вредности
БМИ током радног века код жена линеаран, док је код мушкараца прираст БМИ нелинеаран. Односно, интензивнији је до четрдесете године, након чега је утврђена мање интензивна промена, што је и утврђено применом полиномске функције трећег реда.

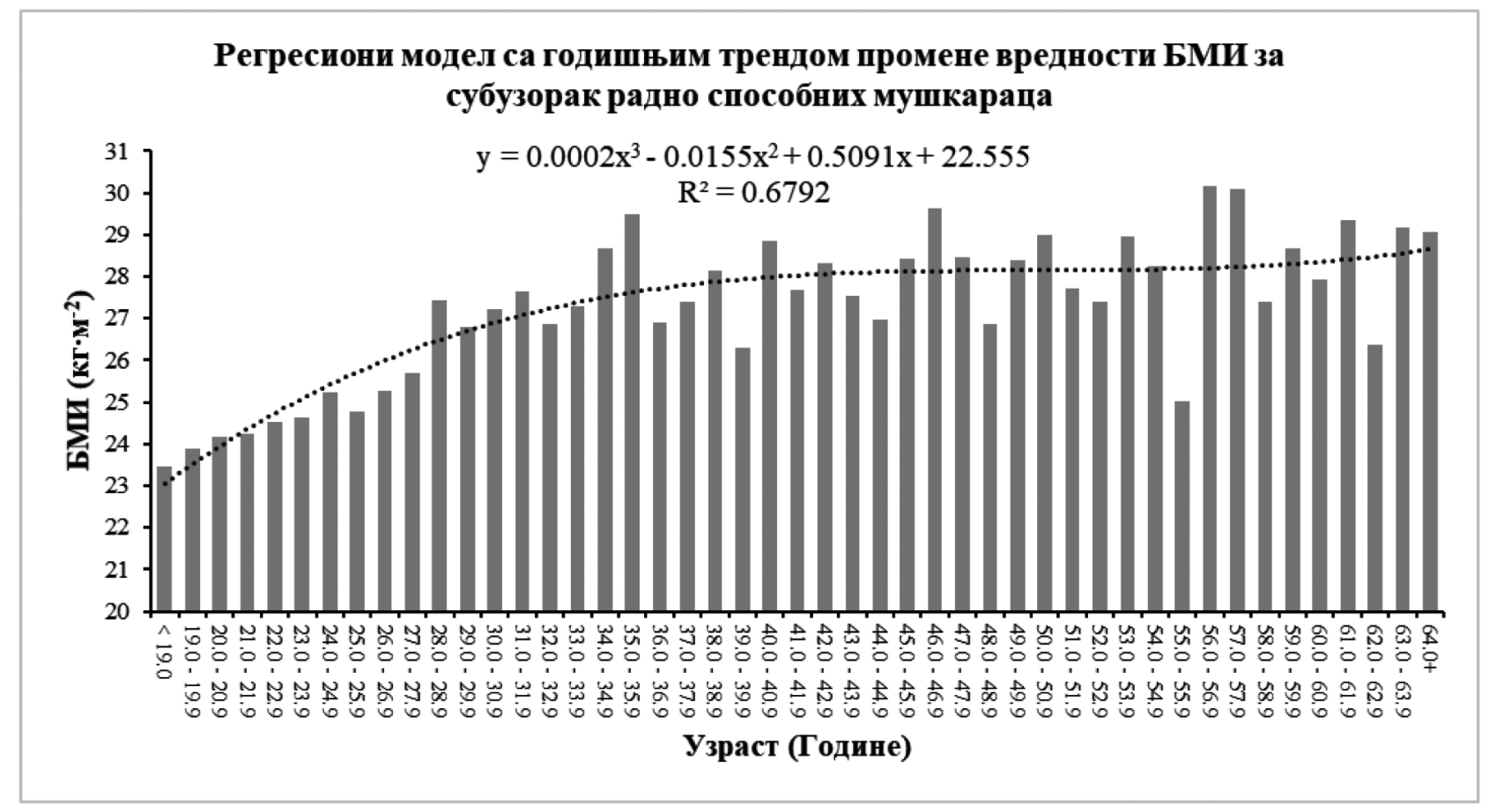

График 3. Регресиони модел са годишњим трендом промене вредности БМИ за субузорак радно способних мушкараца

У Табели 4 приказана је преваленција категорија ухрањености у односу на вредности БМИ у односу на пол и испитиване узрасне субузорке. 
Допсај М., и сар., БМИ: Анализа популационих показатеља..., ФИЗИЧКА КУЛТУРА 2018; 72 (2): $148-160$

Табела 4. Преваленција индекса телесне масе (БМИ) у односу на карактеристичне категорије дате варијабле у функцији пола и узраста испитаника

БМИ - преваленција

\begin{tabular}{|c|c|c|c|c|c|c|c|}
\hline Група & Потхрањени & $\begin{array}{l}\text { Нормално } \\
\text { ухрањени }\end{array}$ & Предгојазни & $\begin{array}{c}\text { Гојазни } \\
\text { класа I }\end{array}$ & $\begin{array}{l}\text { Гојазни } \\
\text { класа II }\end{array}$ & Гојазни & класа III \\
\hline & $<18.49$ & $18.5-24.99$ & $25-29.99$ & $30-34.99$ & $35-39.99$ & $40-49.99$ & $50+$ \\
\hline Укупно & 1.4 & 47.9 & 37.3 & 9.4 & 2.9 & 1.0 & 0.1 \\
\hline Жене & 3.6 & 65.3 & 18.7 & 8.2 & 3.1 & 1.0 & 0.2 \\
\hline Жене, 18-30 год. & 5.9 & 79.6 & 9.0 & 3.7 & 1.5 & 0.3 & 0.0 \\
\hline Жене, 30-40 год. & 2.2 & 64.1 & 18.8 & 8.8 & 4.5 & 1.6 & 0.0 \\
\hline Жене, 40-50 год. & 1.6 & 48.4 & 35.1 & 11.9 & 2.1 & 0.5 & 0.5 \\
\hline Жене, 50-60 год. & 0.6 & 35.9 & 34.3 & 19.3 & 7.7 & 2.2 & 0.0 \\
\hline Жене, 60-65 год. & 0.0 & 19.7 & 36.8 & 25.0 & 9.2 & 6.6 & 2.6 \\
\hline Мушкарци & 0.2 & 37.9 & 48.0 & 10.0 & 2.8 & 1.0 & 0.1 \\
\hline Мушкарци, 18-30 год. & 0.3 & 58.0 & 36.2 & 3.7 & 1.3 & 0.4 & 0.1 \\
\hline Мушкарци, 30-40 год. & 0.0 & 22.6 & 57.5 & 14.6 & 3.7 & 1.5 & 0.3 \\
\hline Мушкарци, 40-50 год. & 0.0 & 19.2 & 56.7 & 18.2 & 4.4 & 1.6 & 0.0 \\
\hline Мушкарци, 50-60 год. & 0.0 & 11.4 & 71.7 & 12.0 & 4.3 & 0.5 & 0.0 \\
\hline Мушкарци, 60-65 год. & 0.0 & 25.8 & 45.2 & 16.1 & 8.1 & 4.8 & 0.0 \\
\hline
\end{tabular}

\section{ДИСКУСИЈА}

Циљ овог рада био је презентовање популационих показатеља ухрањености запосленог становништва Републике Србије, дефинисане на основу вредности Индекса телесне масе (БМИ). Добијени резултати указују на то да се вредности испитиваневаријаблеБМИналазеуприхватљивом опсегу распона резултата, с обзиром на чињеницу да је коефицијент варијације (cV\%), као релативна мера варијабилности, на нивоу укупног узорка и свих испитиваних субузорака мањи од $30 \%$. Другим речима, дати резултати задовољавају критеријуме хомогености (Perić, 2003), те се могу сматрати репрезентативним у смислу даље научне валидације.

Резултати примењене факторске анализе варијансе указују на постојање статистички значајних разлика вредности БМИ на генералном нивоу, како између мушкараца и жена, тако и у односу на узрасне категорије испитаника $(\mathrm{F}=268.885$, $\mathrm{p}<0.001)$, те интеракцију датих фактора $(\mathrm{F}=18.203$. $\mathrm{p}<0.000$ ). На основу добијених резултата (Табела 3) може се тврдити да статистички изузетно значајне разлике $(\mathrm{p}<0.01)$ у вредностима БМИ постоје између мушкараца и жена узраста 18 $30,30-40,40-50$ и 60-65 година, док на узрасту 50-60 година разлике БМИ у односу на пол нису статистички значајне $(\mathrm{p}=0.217)$ (Табела 3). У односу на разлике између узрасних група унутар субузорка мушкараца, на основу добијених резултата (График 1) може се тврдити да мушкарци узраста 18-30 година имају статистички значајно мање вредности БМИ у односу на све остале групе $(\mathrm{p}<0.01)$, док добијене разлике између узрасних група 30-40, 40-50, 50-60 и 60-65 нису статистички значајне. На нивоу субузорка жена утврђено 
је постојање статистички изузетно значајних разлика просечних вредности БМИ између свих испитиваних група у функцији узраста $(\mathrm{p}<0.01)$. У односу на приказане резултате неопходно је истаћи да процентуалне разлике БМИ у односу на просечне вредности узорка у функцији пола указују на то да је и код мушкараца и код жена индекс телесне масе статистички значајно нижи у периоду 18-30 година (6.1 и 7.85\%, респективно), док су код свих осталих субузорака у функцији узраста утврђене више вредности БМИ од просечног са тенденцијом пораста разлика са сваком следећом узрасном категоријом. Ово је посебно изражено на нивоу субузорка жена где је просечан БМИ групе 60-65 година чак 27\% већи у односу на просек укупног узорка жена, што је утврђено и код мушкараца где је БМИ код најстарије групе у просеку за 7.89\% већи у односу на просек укупног узорка мушкараца (График 1).

Применом модела зависности дефинисане су једначине спецификације којим је дефинисан актуелни тренд прираста вредности индекса телесне масе у функцији узраста (по години живота). На нивоу субузорка мушкараца дати модел зависности промене БМИ је дефинисан једначином $\quad \mathrm{y}=0.0002 \cdot \mathrm{x}^{3}-0.0155 \cdot \mathrm{x}^{2}+0.5091 \cdot \mathrm{x}+22.555$ уз коефицијент детерминације на нивоу $\mathrm{R}^{2}=0.68$ (График 2), односно линеарном функцијом следећег облика: $\quad \mathrm{y}=0.0904 \mathrm{x}+25.099$ са коефицијентом детерминације $\mathrm{R}^{2}=0.50$. Другим речима, утврђена константа прираста нивоа ухрањености по години живота износи $0.0904 \mathrm{\kappa г} \cdot \mathrm{M}^{-2}$, односно $90.4 \mathrm{\Gamma} \cdot \mathrm{M}^{-2}$ по години живота.

За субузорак жена тренд прираста БМИ дефинисан је једначином $y=0.1767 \cdot x+21.282$, уз нешто већи проценат објашњене варијансе $\left(\mathrm{R}^{2}=0.78\right)$ (График 3), односно утврђена константа прираста нивоа ухрањености по години живота износи 0.1767 кг $\cdot \mathrm{M}^{-2}$, односно 176.7 г $\mathrm{M}^{-2}$ по години живота.

Иако је у оба случаја, односно за оба узорка у функцији пола, утврђен позитиван тренд прираста телесне масе по јединици површине тела, може се тврдити да вредности БМИ у функцији узраста код жена расту линеарно са константом К=0.1767, док мушкарци у периоду до 40 године доживљавају интензиван прираст БМИ до

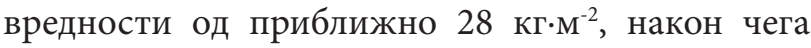
годишњи прираст вредности БМИ стагнира, па мушкарци одржавају релативно непромењене вредности истог све до краја радног века.
У односу на утврђене вредности просечног БМИ на нивоу укупног узорка, може се тврдити да радно активно становништво Републике Србије карактеришу вредности датог индекса на нивоу

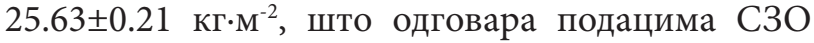
према којима се БМИ на нивоу Републике Србије креће око просечне вредности од 26.1 кг·м-2. Када се добијени подаци упореде са подацима С3О за територију Европе, може се тврдити да се у односу на дати показатељ ухрањености становништва Републике Србије налази у категорији земаља са нешто нижим просечним вредностима БМИ, уз земље као што су Холандија, Португал и Италија где је просечан БМИ на истом нивоу. Имајући у виду чињеницу да се вредности индекса телесне масе у земљама непосредног окружења крећу у границама 25.8 кг·м ${ }^{-2}$ за територију Босне и Херцеговине до 27.4 кг·м'-2 за Републику Хрватску, може се тврдити да су вредности датог показатеља утврђене овим истраживањем нешто ниже у односу на регионални просек, што се у односу на саме вредности може сматрати пожељним (WHO, 2014). Ипак, имајући у виду постојање вишедеценијског глобалног тренда повећања вредности БМИ (NCD Risk Factor Collaboration, 2016) овакав ниво ухрањености радно активног становништва Републике Србије се, без обзира на претходно, може сматрати забрињавајућим.

Посматрано у односу на субузорак жена Републике Србије, утврђене вредности БМИ

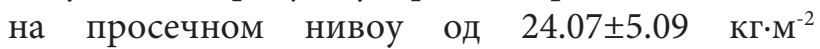
одговарају категорији нормално ухрањених особа. Резултати добијени овим истраживањем слични су онима до којих су дошли ЂорђевићНикић и сарадници (2013) на узорку жена из урбане средине града Београда, где је утврђен

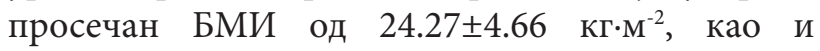
резултатима истраживања које је обухватило жене широм света где су утврђене просечне вредности БМИ на нивоу 24.1 кг·м ${ }^{-2}$ (Finucane et al., 2011). Посматрано у односу на године живота, уочавају се разлике просечних вредности БМИ, при чему добијени подаци указују на постојање негативне тенденције перманентног повећања телесне масе. У том смислу, радно способне жене до тридесете године живота припадају групи нормално ухрањених са просечним вредностима БМИ од 22.18 кг·м м $^{-2}$ Од тридесете године, оне су на горњој граници нормалне ухрањености са вред-

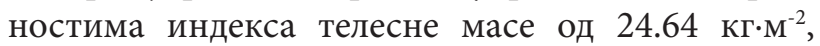


да би у петој и шестој деценији живота ушле у категорију прекомерно ухрањених са БМИ вишим од препоручене вредности СЗО. Такви налази корелирају са истраживањима других аутора која потврђују статистичку значајност везе година и гојазности (Pavlica и сар., 2012; Kelly et al., 2008). Тренд прираста телесне масе од 0.1767 кг $\cdot \mathrm{M}^{-2}$ на годишњем нивоу, жене после 60. године уводи у категорију гојазних. Просечне вредности БМИ од 30.57 кг $\cdot \mathrm{M}^{-2}$ утврђене на нивоу субузорка жена старости 60-65 година веће су у односу на оне утврђене код субузорка мушкараца исте старости где је вредност БМИ на нивоу 28.62 $\kappa \Gamma \cdot \mathrm{M}^{-2}$. Овај податак потврђује налазе који указују на константно повишену преваленцу гојазности код жена у односу на мушкарце, забележену у целом свету (Kelly et al., 2008). Ако се у обзир узме да скоро $20 \%$ становништва не размишља о здрављу када бира начин исхране, те да је свега $8.8 \%$ популације физички активно (при чему мушкарци предњаче у односу на жене) (Институт за јавно здравље Србије [ИЈЗС], 2016), висок проценат прекомерно ухрањених и гојазних жена (31.2\%) на генералном нивоу, као и на нивоу свих субузорака, може се сматрати очекиваним.

У односу на резултате добијене на субузорку мушкараца, утврђено је да су просечне вредности

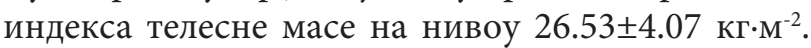
У складу са претходним, може се тврдити да се радно активни мушкарци у Републици Србији, уз занемаривање стратификације у односу на узраст, могу сврстати у категорију прекомерно ухрањених, што је у складу са резултатима добијеним у појединим деловима Војводине (Pavlica и cap., 2010). Ипак, забрињавајућа је чињеница да су вредности датог показатеља ухрањености тек нешто мање у односу на Аустралију и Сједињене Америчке Државе где су утврђене просечне вредности БМИ на нивоу 27.6 и $28.4 \mathrm{\kappa г \cdot} \cdot \mathrm{M}^{-2}$ респективно (Finucane et al., 2011), с обзиром на то да су поменуте земље у светском врху када је у питању проблем прекомерне ухрањености, односно гојазности становништва. Узимајући у обзир стратификацију узорка у односу на узраст, може се тврдити да су најмање вредности БМИ утврђене на узрасту 18-30 година, и то чак $24.91 \pm 3.29 \mathrm{\kappa r} \cdot \mathrm{M}^{-2}$, што се може сматрати граничном вредношћу у односу на прекомерну ухрањеност. На узрасту 30-40 година вредности БМИ код мушкараца достижупросечно $27.74 \pm 4.26$ $\kappa г \cdot \mathrm{M}^{-2}$, док је после четрдесете године евидентна стагнација прираста БМИ који се све до краја радног века, односно узраста 65 година, креће око вредности $28 \mathrm{\kappa г} \cdot \mathrm{M}^{-2}$. Наведени резултати су у сагласности са резултатима раније публикованих истраживања (Pavlica и cap., 2012; Kelly et al., 2008), и нешто виши у односу на резултате популационе студије спроведене у Швајцарској (Kyle et al., 2003). Ипак, треба имати у виду да у поменутој студији није коришћен случајни узорак, те чињеницу да је Швајцарска, према подацима С3О, земља са најмањим просечним БМИ у Европи. С друге стране, резултати ове студије одговарају резултатима добијеним на нивоу Источне Европе (Meyer et al., 1995) где је за мушкарце узраста 50-60 и 60-65 година утврђен просечан БМИ на нивоу $27.5 \pm 3.95$ и $27.5 \pm 3.9$ кг $\cdot \mathrm{M}^{-2}$, респективно.

У односу на преваленцу индекса телесне масе, на основу добијених резултата може се тврдити да на нивоу укупног узорка, $1.4 \%$ испитаника припада категорији потхрањености, $47.9 \%$ испитаника је нормално ухрањено, док је удео прекомерно ухрањених и гојазних особа 37.3 и $13.4 \%$, респективно. Другим речима, утврђено је постојање изражено повећаног удела прекомерно ухрањених и гојазних особа на нивоу $51.7 \%$ радно активног становништва Републике Србије. Ова чињеница посебно је забрињавајућа у контексту континуитета поменутих разултата, с обзиром на чињеницу да је ранијим истраживањем утврђен удео поменутих категорија ухрањености од чак 54\% (Ministarstvo zdravlja Republike Srbije, 2004). Ипак, може се рећи да се, иако је ситуација алармантна, становништво Републике Србије још увек налази далеко од екстремне дистрибуције ухрањености каква карактерише нпр. популацију Мексиканаца који живе у Америци, где су добијени резултати прекомерне телесне масе, односно гојазности, за чак $72.4 \%$ мушкараца и жена (Flegal et al., 2004). У односу на стратификацију узорка према полу, евидентно је да је процентуална заступљеност категорија ухрањености знатно повољнија код жена у односу на мушкарце. У том смислу, категорији нормалне ухрањености припада чак 65.3\%, категорији прекомерне ухрањености, односно гојазности $31.02 \%$, а категорији потхрањености $3.6 \%$ испитаница. Насупрот томе, потхрањених мушкараца има свега $0.2 \%$, док категоријама нормалне ухрањености, односно прекомерне 
ухрањености и гојазности припада 37.9 , односно чак $61.9 \%$ испитаника, респективно. Код гојазних особа је утврђен тренд прираста БМИ са годинама старости што је у складу са резултатима ранијих истраживања (Rotar et al., 2016).

На основу свега наведеног, може се закључити да популацију радно активног становништва Републике Србије карактерише изражено повећан удео прекомерне ухрањености, односно гојазности, како на генералном нивоу, тако и у односу на пол, те да се добијени резултати не разликују у великој мери од осталих земаља Европе (WHO, 2014). Овим се Република Србија сврстава у категорију оних земаља које се практично суочавају са проблемима смањења физичке - радне способности становништва и повећане учесталости патолошких појава (Ђорђевић-Никић и сар., 2013) услед проблема прекомерне ухрањености и гојазности, безмало епидемиолошких размера са тенденцијом даљег напредовања.

\section{ЗАКЉУЧАК}

У односу на утврђене вредности просечног БМИ на нивоу укупног узорка, може се тврдити да радно активно становништво Републике Србије карактеришу вредности датог индекса на нивоу $25.63 \pm 0.21 \kappa \Gamma \cdot \mathrm{M}^{-2}$, док су на нивоу субузорака мушкараца и жена утврђене вредности БМИ на нивоу $26.53 \pm 4.07$ и $24.07 \pm 5.09$ кг $\cdot \mathrm{M}^{-2}$, респективно. У односу на преваленцу, на основу добијених резултата утврђено је да на нивоу укупног узорка, $1.4 \%$ испитаника припада категорији потхрањености, $47.9 \%$ испитаника је нормално ухрањено, док је удео прекомерно ухрањених и гојазних особа 37.3 и $13.4 \%$, респективно. У односу на субузорак жена, категорији нормалне ухрањености припада чак $65.3 \%$, категорији прекомерне ухрањености $18.7 \%$, односно гојазности $12.5 \%$, док категорији потхрањености припада $3.6 \%$ испитаница. На нивоу субузорка мушкараца утврђен је процентуални удео потхрањености на нивоу $0.2 \%$, док категоријама нормалне ухрањености, односно прекомерне ухрањености и гојазности припада $37.9,48.0$ и $13.9 \%$ испитаника, респективно.

Највећа преваленца прекомерне ухрањености и гојазности утврђена је на узрасту од 60-65 година, где на нивоу субузорка мушкараца има $45.2 \%$ предгојазних и $26.0 \%$ гојазних испитаника, односно укупна преваленца особа са повећаном телесном масом је 71.2\%. У односу на узорак жена утврђена је преваленца прекомерне ухрањености на нивоу $36.8 \%$, док је гојазних чак $41.4 \%$. Укупна преваленца повећане телесне масе код жена је на нивоу $78.2 \%$.

На основу дефинисаних модела трендова промене статуса ухрањености у функцији узраста, за субузорак мушкараца утврђена константа прираста нивоа ухрањености по години живота

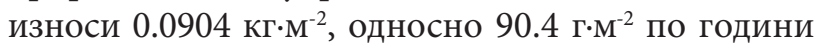
живота, док је код жена на нивоу 0.1767 кг·- ${ }^{-2}$, односно $176.7 \mathrm{r} \cdot \mathrm{M}^{-2}$ по години живота.

Резултати овог истраживања указују да Република Србија следи глобални тренд повећања БМИ као показатеља ухрањености становништва, односно може се закључити да популацију радно активног становништва Републике Србије карактерише повећан удео прекомерне ухрањености, односно гојазности, како на генералном нивоу, тако и у односу на пол.

\section{ЗАХВАЛНОСТ}

Овај рад је део пројекта "Ефекти примењене физичке активности на локомоторни, метаболички, психо-социјални и васпитни статус популације Републике Србије”, број III47015, финансираног од стране Министарства просвете, науке и технолошког развоја Републике Србије научни пројекти, циклус 2011 - 2018. 


\section{ЛИТЕРАТУРА}

1. Bruffaerts, R., Demyttenaere, K., Vilagut, G., Martinez, M., Bonnewyn, A., De Graaf, R., Haro, J.M., Bernert, S., Angermeyer, M.C., Brugha, T., Roick, C. \& Alonso, J. (2008). The relation between body mass index, mental health, and functional disability: a european population perspective. Canadian Journal of Psychiatry, 53(10), 679 - 688.

2. Bungum, T., Satterwhite M., Jackson, A.W. \& Morrow Jr, J.R. (2003). The relationship of body mass index, medical cost, and job absenteeism. American Journal of Health Behaviour, 27(4), 456 - 462.

3. Gába, A., Kapuš, O., Cuberek, R., \& Botek, M. (2015). Comparison of multi- and single-frequency bioelectrical impedance analysis with dual energy X-ray absorptiometry for assessment of body composition in post-menopausal women: effects of body mass index and accelerometerdetermined physical activity. Journal of Human Nutrition and Dietetics, 28, 390 - 400.

4. Ђорђевић-Никић, М., Допсај, М., Ракић, С., Субошић Д., Пребег, Г., Мацура, М., Млађан, Д. \& Кекић, Д. (2013). Морфолошки модел популације радно активних жена Београда мерен методом електричне мултиканалне биоимпеданце: пилот истраживање. Физичка Култура, 67(2), 103 - 112.

5. Илић, Д. (уред.) (2016). Здравствено-статистички годишнак Републике Србије 2015. Београд: Институт за јавно здравље Србије „Др Милан Јовановић Батут“. Београд: Елит медика.

6. Jackson, J.E., Doescher, M.P., Jerant, A.F., \& Hart, G.L. (2005). A national study of obesity prevalence and trends by type of rural county. The Journal of Rural Health, 21(2), 140 - 148.

7. Katzmarzyk, P.T., \& Janssen, I. (2004). The economic costs associated with physical inactivity and obesity in Canada: an update. Canadian Journal of Applied Physiology, 29(1), 90 - 115.

8. Kelly, T., Yang, W., Chen, C-S., Reynolds, K., \& He, J. (2008). Global burden of obesity in 2005 and projections to 2030. International Journal of Obesity, 32, 1431 - 1437.

9. Krishna, A., Razak, F., Lebel, A., Smith, G.D., \& Subramanian, S.V. (2015). Trends in group in- equalities and interindividual inequalities in BMI in the United States, 1993-2012. American Journal of Clinical Nutrition 101, 598 - 605.

10. Kyle, U. G., Schutz, Y., Dupertuis, Y. M., \& Pichard, C. (2003). Body composition interpretation. Contributions of the fat-free mass index and the body fat mass index. Nutrition, 19(7-8), 597-604.

11. Lakerveld, J., Rebah, M.B., Mackenbach, J.D., Charreire, H., Compemolle, S., Glonti, K., Bardos, H., Rutter, H., De Bourdeadhuji, I., Brug, J., Oppert, J-M. (2015). Obesity-related behaviours and BMI in five urban regions across Europe: sampling design and results from the SPOTHLIGHT cross-sectional study. BMJ Open 5(10):e008505.

12. Meyer, H. E., Falch, J. A., O’Neill, T., Tverdal, A., \& Varlow, J. (1995). Height and body mass index in Oslo, Norway, compared to other regions of Europe: Do they explain differences in the incidence of hip fracture? Bone, 17(4), 347-350.

13. Ministarstvo zdravlja Republike Srbije, (2004). Nacionalni vodič za lekare u primarnoj zdravstvenoj zaštiti. Gojaznost. Beograd: Medicinski fakultet Univerziteta u Beogradu, Centar za izdavačku, bibliotečku i informacionu delatnost.

14. NCD Risk Factor Collaboration (NCD-RisC) (2016). Trends in adult body-mass index in 200 countries from 1975 to 2014: a pooled analysis of 1698 population-based measurement studies with 19.2 million participants. Lancet, 387(10026), 1377-1396.

15. Pavlica, T., Božić-Krstić, V., Rakić, R. \& Saka, D. (2012). Prevalencija prekomerne telesne mase i gojaznosti kod odrasle seoske populacije Bačke i Banata. Vojnosanitetski Pregled, 69(10), 833 - 839.

16. Pavlica, T., Božić-Krstić, V., Rakić, R. \& Srdić, B. (2010). Uhranjenost i distribucija masnog tkiva kod zdravih odraslih osoba $\mathrm{u}$ nekim mestima centralnog Banata. Medicinski Pregled, LXIII (12), $21-26$.

17. Perić, D. (2003). Statistika primenjena u sportu i fizičkom vaspitanju. Beograd, Fakultet sporta i fizičkog vaspitanja.

18. Peytremann-Bridevaux, I., Faeh D. \& Santos-Eggimann, B. (2007). Prevalence of overweight and obesity in rural and urban settings of 10 European countries. Preventive Medicine, 44, 442 - 446. 
19. Prentice, M.A., \& Jebb, A.S. (2001). Beyond body mass index. Obesity Reviews, 2, 141 - 147.

20. Rotar, O., Boyarinova, M., Orlov, A., Solntsev, V., Zhernakova, Y., Shalnova, S., Deev, A., Konradi, A., Baranova, E., Chazova, I., Boytsov, S. \& Shlyakhto, E. (2016). Metabolically healthy obese and metabolically unhealthy non-obese phenotypes in a Russian population. European Journal of Epidemiology, 32(3), 251-254.

21. Finucane, M., Stevens, G.A., Cowan, M.J., Danaei, D., Lin, J.K., Paciorek, C.J., Singh, G.M., Gutierez, H.R., Lu, Y., Bahalim, A.D., Farzadfar, F., Riley, L.M. \& Ezzati, M. (2011). National, regional, and global trends in body-mass index since 1980: systematic analsysis of health examination surveys and epidemiological studies with 960 countryyears and 9.1 million participants. Lancet, 377, 557-567.

22. Flegal, K. M., Ogden, C. L. \&. Carroll, M. D. (2004). Prevalence and trends in overweight in mexican-american adults and children. Nutrition Reviews, 62(7), 144-148.
23. Flegal, K.M., Carroll, M.D., Kit, B.K. \& Ogden, C.L. (2012). Prevalence of obesity and trends in the distribution of body mass index among US adults, 1999-2010. Journal of American Medical Association, 307(5), 491 - 497.

24. Weisell, R.C. (2002). Body mass index as an indicator of obesity. Asia Pacific Journal of Clinical Nutrition 11(Suppl), S681 - S684.

25. World Health Organization. Global status report on noncommunicable diseases (2014). Attaining the nine global noncommunicable diseases targets; a shared responsibility. Geneva: WHO.

26. World Health Organization. Western Pacific Region. (2000). The Asia-Pacific perspective: Redefining Obesity and its treatment. International Obesity Task Force. 